\title{
Lactational programming of glucose homeostasis: a window of opportunity
}

\author{
Lindsay Ellsworth, Emma Harman, Vasantha Padmanabhan and Brigid Gregg \\ Department of Pediatrics, University of Michigan, Ann Arbor, Michigan, USA \\ Correspondence should be addressed to B Gregg; Email: greggb@med.umich.edu
}

\begin{abstract}
The window of lactation is a critical period during which nutritional and environmental exposures impact lifelong metabolic disease risk. Significant organ and tissue development, organ expansion and maturation of cellular functions occur during the lactation period, making this a vulnerable time during which transient insults can have lasting effects. This review will cover current literature on factors influencing lactational programming such as milk composition, maternal health status and environmental endocrine disruptors. The underlying mechanisms that have the potential to contribute to lactational programming of glucose homeostasis will also be addressed, as well as potential interventions to reduce offspring metabolic disease risk.

Reproduction (2018) 156 R23-R42
\end{abstract}

\section{Introduction}

David Barker's landmark epidemiologic study in the 1980s connected early life stressors to the development of ischemic heart disease in adult life (Barker et al. 1989). These initial studies led to the 'fetal origins of adult disease' hypothesis, which is based on the findings that undernutrition in pregnancy increases the long-term risk for adult diseases (Barker et al. 1989, Nijland et al. 2008). These discoveries have been replicated in human epidemiologic studies as well as studies with small and large animal experimental models (Nathanielsz 2006, Nijland et al. 2008, Padmanabhan et al. 2016). Because metabolic tissues are exquisitely sensitive to developmental stressors, developmental insults frequently alter metabolic outcomes in offspring manifesting as obesity, insulin resistance, abnormal blood glucose levels and diabetes (Devaskar \& Thamotharan 2007).

Developmental programming studies have demonstrated that the adult function of organ systems can be organized during early life and that the critical windows of susceptibility to insults differ between different organ systems. The windows of susceptibility of the organs involved in programming and maintaining glucose homeostasis, the programming stressors, and the mechanism behind such programming, are important aspects to consider in the developmental origin of metabolic diseases. Organ systems involved in maintaining glucose homeostasis are susceptible to reprogramming throughout the stages of tissue differentiation and organ development, beginning during fetal life and often continuing through infancy.
The ability to manipulate maternal and offspring diet in experimental animal models helps researchers gain key mechanistic insights into specific programming influences. In translating findings from animal models to humans, one must recognize that variations in the critical windows of organ development exist between precocial (e.g. monkeys, sheep, human) and altricial (e.g. mouse, rat) species (Fig. 1). Furthermore, while the in utero period is undeniably a period of critical organ development, the early postnatal window has an independent and significant contribution to long-term outcomes that is just beginning to be understood.

The lactation period is a critical window of susceptibility, as organ differentiation often continues during the early postnatal period. Lactational programming refers to programming that stems from an exposure that occurs during the period when the mother is nursing her infant, which may lead to changes in the nutrients, hormones or bioactive components in the milk. The 'lactocrine hypothesis' as described by Bartol connected changes in the milk-borne growth factor, relaxin, delivered to nursing offspring to programming of relaxin/insulin like family peptide receptor 1-positive target tissues in the female porcine reproductive tract (Bartol et al. 2008, Frankshun et al. 2011). Thus, alterations in milk composition can reprogram the developmental trajectory of organs leading to altered offspring outcomes in adult life (Bartol et al. 2013).

The period of lactation can be divided into a milk only phase in which offspring are fully dependent on maternal milk, followed by a mixed feeding/weaning period at which time complementary feedings are necessary to sustain infant growth (Langer 2008). The 


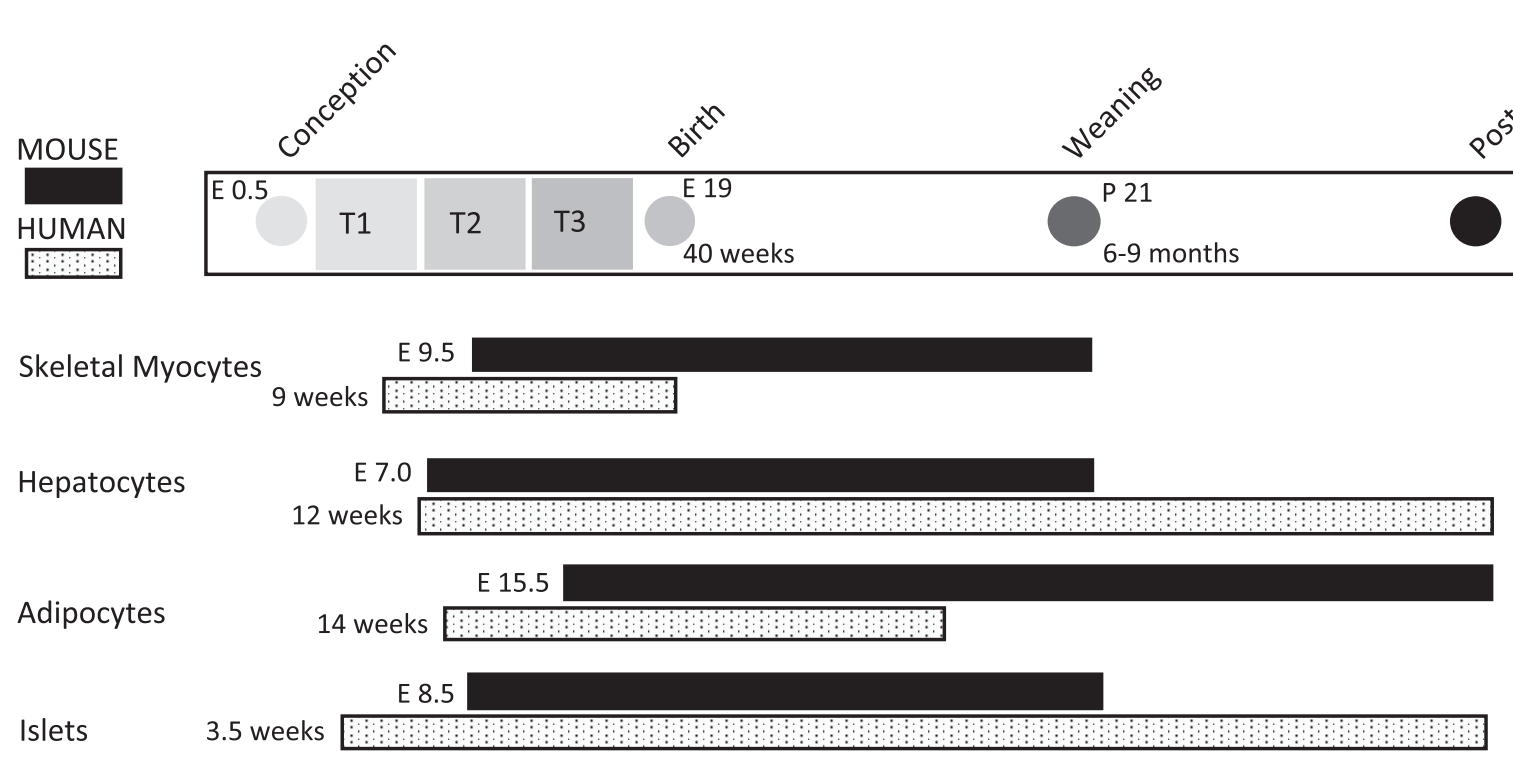

Figure 1 Timelines for mouse and human metabolic tissue development.

transition from milk exclusive to complementary food introduction differs by animal species (Langer 2008, Stringer et al. 2014, Wells 2014). For humans, milk is the only recommended substance for infant nutrition until at least 4-6 months of age, when exposure to complementary foods begins. Thus, in the early weeks of life for mammals this essential milk can serve as a significant programming agent. The role of milk intake during this period of programming cannot be viewed as the sole programming regulator, as maternal-infant interactions including care-giving and bonding during suckling also play key roles in early life programming (Hinde \& Capitanio 2010, Macrì et al. 2011). The period of lactation provides a unique window of opportunity within the 'first 1000 days' to intervene and reduce lifelong metabolic disease risk from a public health standpoint. A better understanding of the developmental plasticity that occurs in metabolic tissues during this window is essential to develop interventions.

To address lactation-specific contributions to metabolic programming, this review will focus on animal and human studies that involve manipulations exclusively during the lactation period with documented effects on metabolic outcomes. Exposures during pregnancy are only included if a milk composition analysis was performed. This review will address factors influencing lactation and mechanisms by which lactational exposures program offspring metabolic tissues, highlighting sex-specific outcomes when they are reported. Table 1 summarizes the human and animal studies of lactational programming from groups that examined offspring metabolic endpoints. Sex-specific programmed effects and milk composition changes are noted in Table 1 when they have been reported.

\section{Lactational/early postnatal window for programming of glucose homeostasis}

The ability of mammals to maintain glucose homeostasis depends on the concerted functions of the brain, pancreatic islet cells, hepatocytes, myocytes and adipose tissues (Tirone \& Brunicardi 2001). When glucose is ingested, it enters the circulation and is transported to the pancreas (Thorens \& Mueckler 2010). The pancreatic beta cells then sense the glucose and secrete insulin, the major effector for glucose uptake by the body. Insulin stimulates glucose uptake in peripheral tissues including the liver, skeletal muscle and adipocytes followed by metabolism and/or storage of glycogen (Patti \& Kahn 1998). When the demand on any of these organs becomes too high, compensatory actions take place to regain homeostasis (Cerf et al. 2012). This compensation may be defective if the differentiation of metabolic tissues is compromised (Shrayyef \& Gerich 2010). Because the organs involved in maintaining glucose homeostasis continue differentiation and growth during the lactation period (Fig. 1), they are vulnerable to programming influences during the lactational window.

Exposures during the lactational window not only have programming effects, but may also have the potential to amplify the effects of in utero exposures on lifelong metabolic disease risk. Many studies have shown that while insults during fetal life may have programmed a 'thrifty' phenotype to promote shortterm adaptations allowing for survival, a second insult occurring postnatally could unmask or amplify early programming through a 'second-hit' thus contributing to the development or severity of the metabolic dysfunctions (Gluckman et al. 2008, Padmanabhan et al. 2016, Puttabyatappa et al. 2016). For instance, 
Table 1 Summary of animal and human nutrient and environmental exposures during lactation.

\begin{tabular}{|c|c|c|c|c|}
\hline $\begin{array}{l}\text { Programming } \\
\text { influence }\end{array}$ & Author & Species & $\begin{array}{l}\text { Breast milk } \\
\text { composition }\end{array}$ & Sex differences \\
\hline \multirow[t]{2}{*}{ Undernutrition } & $\begin{array}{l}\text { Sadagurski et al. } \\
(2014)\end{array}$ & Mouse & Not evaluated & $\begin{array}{l}\text { Both male and female } \\
\text { mice became insulin } \\
\text { sensitive at different } \\
\text { time points in } \\
\text { adulthood (later in } \\
\text { females). Males only } \\
\text { had reduced beta cell } \\
\text { mass and proliferation } \\
\text { rate }\end{array}$ \\
\hline & $\begin{array}{l}\text { Lopez-Soldado et al. } \\
\text { (2006) }\end{array}$ & Rat & $\begin{array}{l}\text { Triacylglycerol } \\
\text { concentration lower } \\
\text { in dams with large } \\
\text { litters }\end{array}$ & $\begin{array}{l}\text { Males had decreased } \\
\text { lumbar and } \\
\text { epididymal adipose } \\
\text { weights, lower } \\
\text { weight, reduced } \\
\text { VLDL-TG (adult) }\end{array}$ \\
\hline Overnutrition & Glavas et al. (2010) & Mouse & Not evaluated & $\begin{array}{l}\text { Male rats studied } \\
\text { exclusively }\end{array}$ \\
\hline
\end{tabular}

Metabolic outcomes and mechanisms

Reduced body fat and perigonadal adipocyte size, increased lean body weight, lower fasting leptin, increased insulin sensitivity in pups of a crowded litter

Bernardo et al. (2016) Mouse Not evaluated

Male mice studied exclusively

$\begin{array}{llll}\begin{array}{c}\text { Plagemann et al. } \\ \text { (1992) }\end{array} & \text { Rat } & \text { Not evaluated } & \begin{array}{c}\text { Male rats studied } \\ \text { exclusively }\end{array} \\ \text { Xiao et al. (2007) } & \text { Rat } & \text { Not evaluated } & \begin{array}{c}\text { Male rats studied } \\ \text { exclusively }\end{array} \\ \text { Rajia et al. (2010) } & \text { Rat } & \text { Not evaluated } & \begin{array}{c}\text { Male rats studied } \\ \text { exclusively }\end{array} \\ & & & \\ \text { Bei et al. (2015) } & \text { Rat } & \text { Not evaluated } & \begin{array}{c}\text { Male rats studied } \\ \text { exclusively }\end{array}\end{array}$

Lewis et al. (1989) Primate Not evaluated

Lewis et al. (1992) Primate Not evaluated

$$
\text { exclusively }
$$

Female baboons had increased fat mass and adipocyte volume; overfed males had no weight change but increased fat in visceral and subcutaneous depots Female baboons studied exclusively
Decreased total weight and adipose weight (males), increased insulin sensitivity in pups of a large litter

Increased body weight, increased fat deposits (visceral, epididymal, retroperitoneal) and hyperleptinemia with hypothalamic leptin resistance. As an adult, insulin resistance and obesity developed when challenged with a high-fat diet

Increased body weight and visceral fat, increased liver weight with hyperinsulinemia and hyperglycemia. Impaired insulin signaling in the heart with mild mitochondrial structure abnormalities

Increased body weight gain persisting into adulthood, increased systolic blood pressure and elevated basal insulin level

Increase in body weight, increased food intake, impaired brown adipose tissue thermogenic response to cold stimulus

Increased weight and white adipose tissue on chow diet in small litter and impaired glucose tolerance and liver fat on adult HFD re-challenge in the small litter offspring

Adult insulin resistance, increased free fatty acid and increased triglycerides levels, increased body weight and white adipose tissue. Impaired insulin signaling with downregulation of GLUT4 receptors in adipose tissue and skeletal muscle

Obese phenotype (female) baboons, potentially mediated by increased adipocyte volume

Early increased insulin secretion in response to meals but not at later time points. Early blunted cortisol responses that resolved by 18 weeks of age. Increased weight in females after puberty and no change in fat cell volume 
Table 1 Continued

\begin{tabular}{lllll}
\hline $\begin{array}{l}\text { Programming } \\
\text { influence }\end{array}$ & Author & Species & $\begin{array}{l}\text { Breast milk } \\
\text { composition }\end{array}$ & Sex differences \\
\hline Carbohydrate & $\begin{array}{c}\text { Early outcomes: } \\
\text { Srinivasan et al. } \\
(2000,2001)\end{array}$ & Rat & Not evaluated & $\begin{array}{c}\text { Sex differences not } \\
\text { analyzed or male rats } \\
\text { exclusively studied }\end{array}$ \\
\hline
\end{tabular}

Adult outcomes:

Hiremagalur et al. (1993), Aalinkeel et al. (2001), Srinivasan et al. (2013)

Goran et al. (2017)

Human

Breast milk sugars measured

Protein

Kucia et al. (2011)

Mouse

Decrease in milk lactose content with high-protein diet

Moura et al. (2002)

Rat

Not evaluated

Morimoto et al. (2012)

Rodrigues et al. (2017)

European Childhood Obesity Trial:

Koletzko et al.

(2009), Escribano

et al. (2012), Weber

et al. (2014)
No effect of infant sex

Similar outcomes for males and females

Sex differences not analyzed

Male rats studied exclusively

Female rat pups nursed on high-protein cow's milk developed increased fat, hyperphagia and lower insulin secretion. Males had lower overall body protein Analysis adjusted for sex
Metabolic outcomes and mechanisms

Hyperinsulinemia related to increased GLP-1 and GLP-1 receptor mRNA with increased downstream signaling pathway activity; increased activity of protein kinases that mediate insulin secretion in offspring islets; increased insulin biosynthesis with increased PDX1 levels with increased mRNA of factors regulating $P d x 1$ expression

$\mathrm{HCD}$, offspring developed increased body, perigonadal fat pad and liver weights; increased liver fat; increased adipocyte size in epididymal tissues and increased lipogenic enzyme activity (Hiremagalur et al. 1993). Offspring also showed increased basal and stimulated insulin levels with underlying increases islet in Glut2 and preproinsulin mRNA, along with upstream factors that regulate preproinsulin transcription (Aalinkeel et al. 2001). Pair feeding after HCD reduced weight gain and serum hormones normalized, however islets remained hypersecretory (Srinivasan et al. 2013)

Breast milk fructose composition at 6 months related to increased infant growth in weight, lean mass and fat mass

A maternal high-protein diet during lactation showed reduced litter mass linked to decreases in mammary gland mRNA levels with impaired lactation

Maternal low-protein diet led to increased offspring plasma insulin and leptin during lactation and decreased during adulthood during a re-challenge protein-free diet

Rat offspring with maternal proteinrestriction showed increased islet insulin secretion in vitro at weaning but impaired insulin secretion after glucose challenge as adults

Female rats developed hypoinsulinemia and normoglycemia while males showed unchanged insulin levels and hyperglycemia when nursed on a high-protein cow's milk diet, potentially mediated by estrogen and prolactin

At age 2 years, infant fed a higher protein diet had increased Wt/L Z-score and increased weight (Koletzko et al. 2009). Increased weight gain velocity and fat mass for first 6 months of life and a higher BMI at 12, but not 24 months for infants given high-protein formula (Escribano et al. 2012). Children given high-protein formula showed increased BMI at 6 years of age and 2.4 times the risk of obesity as compared to the low-protein group (Weber et al. 2014)

(Continued) 
Table 1 Continued

\begin{tabular}{|c|c|c|c|c|c|}
\hline $\begin{array}{l}\text { Programming } \\
\text { influence }\end{array}$ & Author & Species & $\begin{array}{l}\text { Breast milk } \\
\text { composition }\end{array}$ & Sex differences & Metabolic outcomes and mechanisms \\
\hline \multirow[t]{4}{*}{ Fat } & Vogt et al. (2014) & Mouse & $\begin{array}{l}\text { Increase in milk } \\
\text { glucose and insulin } \\
\text { content from dams } \\
\text { fed a high-fat diet } \\
\text { during lactation }\end{array}$ & $\begin{array}{l}\text { Male mice studied } \\
\text { exclusively }\end{array}$ & $\begin{array}{l}\text { A maternal HFD during lactation } \\
\text { showed an obese phenotype and } \\
\text { impaired glucose tolerance in } \\
\text { offspring, mediated by an impairment } \\
\text { of axonal projections to the PVH area } \\
\text { of the hypothalamus and decreased } \\
\text { parasympathetic innervations of the } \\
\text { pancreatic beta-cells }\end{array}$ \\
\hline & Liang et al. (2016) & Mouse & $\begin{array}{l}\text { Increase in milk } \\
\text { triglyceride levels }\end{array}$ & $\begin{array}{l}\text { Male mice studied } \\
\text { exclusively }\end{array}$ & $\begin{array}{l}\text { A maternal HFD during lactation } \\
\text { showed increased body weight and } \\
\text { fat mass in adults with impaired } \\
\text { glucose tolerance and insulin } \\
\text { sensitivity and an abnormal brown } \\
\text { adipose tissue response to cold }\end{array}$ \\
\hline & Sun et al. (2012) & Rat & $\begin{array}{l}\text { Increase in milk leptin } \\
\text { and fat content at } \\
\text { postnatal day } 21\end{array}$ & $\begin{array}{l}\text { Similar results in males } \\
\text { and females }\end{array}$ & $\begin{array}{l}\text { Rat pups cross-fostered to dams fed } \\
\text { HFD during pregnancy and lactation } \\
\text { showed greater adiposity with an } \\
\text { increase in subcutaneous fat, } \\
\text { increased plasma leptin, elevated } \\
\text { insulin levels associated with a } \\
\text { reduction in STAT3 response to leptin } \\
\text { in the hypothalamus }\end{array}$ \\
\hline & $\begin{array}{l}\text { Masuyama and } \\
\text { Hiramatsu (2014) }\end{array}$ & Rat & Not evaluated & $\begin{array}{l}\text { Male rats showed an } \\
\text { increased leptin surge } \\
\text { compared to females }\end{array}$ & $\begin{array}{l}\text { Rat pups cross-fostered to dams fed } \\
\text { HFD during lactation showed } \\
\text { increased fat mass gain, food intake, } \\
\text { glucose intolerance and insulin } \\
\text { resistance along with increased } \\
\text { mRNA expression of leptin, } \\
\text { triglycerides and adiponectin }\end{array}$ \\
\hline \multirow[t]{6}{*}{ Fatty acids } & Oosting et al. (2010) & Mouse & $\begin{array}{l}\text { Increase milk n-3 } \\
\text { LC-PUFAs in dams } \\
\text { supplemented with } \\
\text { n-3 }\end{array}$ & $\begin{array}{l}\text { Male mice studied } \\
\text { exclusively }\end{array}$ & $\begin{array}{l}\text { Mice fed an } \mathrm{n}-3 \text { rich postnatal diet } \\
\text { showed a } 30 \% \text { reduction in fat } \\
\text { accumulation when challenged in } \\
\text { adulthood with a western style diet }\end{array}$ \\
\hline & $\begin{array}{l}\text { Korotkova et al. } \\
(2002 a, b)\end{array}$ & Rat & $\begin{array}{l}\text { Increase in milk leptin } \\
\text { and saturation PUFAs } \\
\text { in dams fed EFAD. } \\
\text { No difference in } \\
\text { leptin level with n-3 } \\
\text { and n-6 } \\
\text { supplementation }\end{array}$ & $\begin{array}{l}\text { Sex differences not } \\
\text { analyzed }\end{array}$ & $\begin{array}{l}\text { Decreased serum leptin levels and } \\
\text { leptin mRNA in inguinal white } \\
\text { adipose tissues of offspring suckling to } \\
\text { dams on EFAD. Pups receiving } \\
\text { high-n-3 diet developed lower body } \\
\text { weight, inguinal fat pad weight, } \\
\text { adipocyte size and serum leptin. Pups } \\
\text { receiving increased ratio n-6/n-3 PUFA } \\
\text { had increased body weight, inguinal } \\
\text { fat pad weight and adipocyte size }\end{array}$ \\
\hline & Hadley et al. (2017) & Rat & $\begin{array}{l}\text { Dams supplemented } \\
\text { with a combination } \\
\text { ARA and DHA diet } \\
\text { had milk with } \\
\text { increased ARA and } \\
\text { DHA }\end{array}$ & $\begin{array}{l}\text { Male mice studied } \\
\text { exclusively }\end{array}$ & $\begin{array}{l}\text { Offspring cross-fostered to dams } \\
\text { supplemented with a combination } \\
\text { ARA and DHA diet showed increased } \\
\text { body weight }\end{array}$ \\
\hline & Grant et al. (2011) & Primate & $\begin{array}{l}\text { Decrease in milk } \\
\text { protein, DHA, EPA } \\
\text { levels and increase } \\
\text { insulin }\end{array}$ & $\begin{array}{l}\text { Sex differences not } \\
\text { analyzed }\end{array}$ & $\begin{array}{l}\text { Offspring developed increased body } \\
\text { fat and lower lean body mass when } \\
\text { maternal diet was supplemented with } \\
\text { omega- } 6 \text {. Infant DHA level at } \\
16 \text { weeks had a minor negative } \\
\text { association with weight at age } 1 \text { and } \\
2 \text { years }\end{array}$ \\
\hline & Makrides et al. (1999) & Human & Not evaluated & $\begin{array}{l}\text { Analysis adjusted for } \\
\text { sex }\end{array}$ & $\begin{array}{l}\text { Fish oil supplementation associated } \\
\text { with a } 0.65 \mathrm{~kg} / \mathrm{m}^{2} \text { increase in BMI at } \\
\text { age } 2.5 \text { years }\end{array}$ \\
\hline & $\begin{array}{l}\text { Lauritzen et al. } \\
\text { (2005), Asserhøj } \\
\text { et al. (2009) }\end{array}$ & Human & Not evaluated & $\begin{array}{l}\text { Analysis adjusted for } \\
\text { sex }\end{array}$ & $\begin{array}{l}\text { Maternal erythrocyte DHA level } \\
\text { positively associated with offspring } \\
\text { BMI and waist circumference } \\
\text { (Lauritzen et al. 2005). At age } 7 \text { the } \\
\text { association no longer remained } \\
\text { (Asserhøj et al. 2009) }\end{array}$ \\
\hline
\end{tabular}


Table 1 Continued

\begin{tabular}{|c|c|c|c|c|c|}
\hline $\begin{array}{l}\text { Programming } \\
\text { influence }\end{array}$ & Author & Species & $\begin{array}{l}\text { Breast milk } \\
\text { composition }\end{array}$ & Sex differences & Metabolic outcomes and mechanisms \\
\hline & Helland et al. (2008) & Human & $\begin{array}{l}\text { Measured PUFAs in } \\
\text { breast milk }\end{array}$ & $\begin{array}{l}\text { Analysis adjusted for } \\
\text { sex }\end{array}$ & $\begin{array}{l}\text { Alpha-linoleic acid levels in breast } \\
\text { milk sampled at } 3 \text {-months positively } \\
\text { correlated with child BMI at } 7 \text { years }\end{array}$ \\
\hline & Much et al. (2013) & Human & $\begin{array}{l}\text { Maternal n-3 } \\
\text { supplementation and } \\
\text { reduced ARA intake } \\
\text { showed a reduced } \\
\text { n- } 6 \text { to } n-3 \text { ratio }\end{array}$ & $\begin{array}{l}\text { Analysis adjusted for } \\
\text { sex }\end{array}$ & $\begin{array}{l}\text { Breast milk DHA and n- } 3 \text { fatty acids } \\
\text { have a positive relationship with } \\
\text { infant body fat subcutaneous to } \\
\text { pre-peritoneal ratios at } 6 \text { weeks } \\
\text { of age }\end{array}$ \\
\hline \multirow[t]{3}{*}{$\begin{array}{l}\text { Maternal } \\
\text { diabetes }\end{array}$} & $\begin{array}{l}\text { Fahrenkrog et al. } \\
\text { (2004) }\end{array}$ & Rat & Not evaluated & $\begin{array}{l}\text { Sex differences not } \\
\text { analyzed }\end{array}$ & $\begin{array}{l}\text { Reduced growth rate (weight and } \\
\text { length) in offspring of diabetic dams } \\
\text { potentially due to malprogramming } \\
\text { of the hypothalamus. No difference } \\
\text { in plasma insulin, leptin } \\
\text { concentrations }\end{array}$ \\
\hline & $\begin{array}{l}\text { Plagemann et al. } \\
\text { (2002) }\end{array}$ & Human & Not evaluated & $\begin{array}{l}\text { Sex differences not } \\
\text { analyzed }\end{array}$ & $\begin{array}{l}\text { Infants of diabetic mothers receiving } \\
\text { banked breast milk as } \\
\text { supplementation were protected } \\
\text { against obesity at } 2 \text { years old }\end{array}$ \\
\hline & $\begin{array}{l}\text { Schaefer-Graf et al. } \\
\text { (2006) }\end{array}$ & Human & Not evaluated & $\begin{array}{l}\text { Sex differences not } \\
\text { analyzed }\end{array}$ & $\begin{array}{l}\text { Offspring of obese mothers with } \\
\text { gestational diabetes had a decreased } \\
\text { risk of childhood overweight if they } \\
\text { were breastfed }>3 \text { months }\end{array}$ \\
\hline \multirow[t]{4}{*}{ Maternal obesity } & Gorski et al. (2006) & Rat & $\begin{array}{l}\text { Diet-induced obese } \\
\text { dams had higher } \\
\text { insulin and decreased } \\
\text { total PUFAs }\end{array}$ & $\begin{array}{l}\text { Male rats studied } \\
\text { exclusively }\end{array}$ & $\begin{array}{l}\text { Improved insulin sensitivity with } \\
\text { maintained obese phenotype in } \\
\text { offspring of obese dams fostered } \\
\text { to lean dams. Lean dam offspring } \\
\text { then given a high-energy diet } \\
\text { developed obesity and insulin } \\
\text { resistance }\end{array}$ \\
\hline & $\begin{array}{l}\text { Bernstein and Hinde } \\
\text { (2016) }\end{array}$ & Primate & $\begin{array}{l}\text { Milk growth factors } \\
\text { measured }\end{array}$ & $\begin{array}{l}\text { Increased female } \\
\text { offspring growth rate } \\
\text { with lower milk } \\
\text { EGF-receptor }\end{array}$ & $\begin{array}{l}\text { Lower EGF and EGF-receptor in } \\
\text { increased weight mothers. Higher } \\
\text { EGF and EGF-R associated with } \\
\text { increased infant body mass }\end{array}$ \\
\hline & $\begin{array}{l}\text { Mayer-Davis et al. } \\
\text { (2006) }\end{array}$ & Human & $\begin{array}{l}\text { Not evaluated, } \\
\text { retrospective report }\end{array}$ & $\begin{array}{l}\text { Analysis adjusted for } \\
\text { sex }\end{array}$ & $\begin{array}{l}\text { Self-report of exclusive breast feeding } \\
\text { to } 6 \text { months associated with an odds } \\
\text { ratio of } 0.75 \text { for overweight in } \\
\text { children age } 9-14 \text { years }\end{array}$ \\
\hline & Fields et al. (2017) & Human & $\begin{array}{l}\text { Insulin and leptin } \\
\text { levels increased with } \\
\text { increased BMI }\end{array}$ & $\begin{array}{l}\text { Maternal BMI } \\
\text { correlates with higher } \\
\text { human breast milk } \\
\text { insulin levels for } \\
\text { mothers who gave } \\
\text { birth to female infants }\end{array}$ & $\begin{array}{l}\text { High-milk leptin associated with } \\
\text { decreased infant length and fat mass } \\
\text { at } 6 \text { months }\end{array}$ \\
\hline \multirow[t]{3}{*}{ Stress } & Dantzer et al. (2013) & Squirrel & Not evaluated & $\begin{array}{l}\text { Sex differences not } \\
\text { analyzed }\end{array}$ & $\begin{array}{l}\text { Accelerated offspring postnatal growth } \\
\text { rate with maternal physiological } \\
\text { stress }\end{array}$ \\
\hline & Hinde et al. (2015) & Primate & $\begin{array}{l}\text { Higher milk cortisol } \\
\text { with stress. Measured } \\
\text { milk fat, protein, } \\
\text { sugars }\end{array}$ & $\begin{array}{l}\text { Females more sensitive } \\
\text { to milk cortisol in } \\
\text { relation to } \\
\text { temperament scores }\end{array}$ & $\begin{array}{l}\text { At } 1 \text { month, infant growth was highest } \\
\text { with higher milk cortisol and milk } \\
\text { energy peaked }\end{array}$ \\
\hline & $\begin{array}{l}\text { Hahn-Holbrook et al. } \\
\text { (2016) }\end{array}$ & Human & $\begin{array}{l}\text { Cortisol is found in } \\
\text { human breast milk }\end{array}$ & $\begin{array}{l}\text { In females, decreased } \\
\text { rapid early BMI gain } \\
\text { linked to cortisol } \\
\text { breast milk levels }\end{array}$ & $\begin{array}{l}\text { Increased milk cortisol associated with } \\
\text { lower BMI at } 2 \text { years }\end{array}$ \\
\hline \multirow[t]{2}{*}{ Smoking } & $\begin{array}{l}\text { de Oliveira et al. } \\
\text { (2010) }\end{array}$ & Rat & $\begin{array}{l}\text { Dams treated with } \\
\text { nicotine infusion had } \\
\text { milk with higher } \\
\text { lactose and energy } \\
\text { content. Cotinine } \\
\text { levels were similar in } \\
\text { milk and plasma }\end{array}$ & $\begin{array}{l}\text { Male rats studied } \\
\text { exclusively }\end{array}$ & $\begin{array}{l}\text { Offspring with increased body weight, } \\
\text { adipocyte hypertrophy, insulin and } \\
\text { leptin levels as adults when exposed } \\
\text { to nicotine directly, possibly related } \\
\text { to reduced protein in leptin signaling }\end{array}$ \\
\hline & $\begin{array}{l}\text { Santos-Silva et al. } \\
\text { (2011) }\end{array}$ & Rat & $\begin{array}{l}\text { Smoke-exposed dams } \\
\text { showed milk with } \\
\text { increased lactose and } \\
\text { triglycerides }\end{array}$ & $\begin{array}{l}\text { Male rats studied } \\
\text { exclusively }\end{array}$ & $\begin{array}{l}\text { Pups had lower total fat, } \\
\text { hyperinsulinemia, } \\
\text { hypertriglyceridemia }\end{array}$ \\
\hline
\end{tabular}


Table 1 Continued

\begin{tabular}{|c|c|c|c|c|c|}
\hline $\begin{array}{l}\text { Programming } \\
\text { influence }\end{array}$ & Author & Species & $\begin{array}{l}\text { Breast milk } \\
\text { composition }\end{array}$ & Sex differences & Metabolic outcomes and mechanisms \\
\hline & $\begin{array}{l}\text { Santos-Silva et al. } \\
\text { (2013) }\end{array}$ & Rat & Not evaluated & $\begin{array}{l}\text { Male rats studied } \\
\text { exclusively }\end{array}$ & $\begin{array}{l}\text { In adulthood, pups exposed to smoke } \\
\text { had increased total and visceral fat } \\
\text { mass, dyslipidemia, increase leptin } \\
\text { and adiponectin }\end{array}$ \\
\hline \multirow[t]{2}{*}{ Alcohol } & $\begin{array}{l}\text { Tavares Do Carmo } \\
\text { et al. (1999) }\end{array}$ & Rat & $\begin{array}{l}\text { Maternal ethanol } \\
\text { intake decreases milk } \\
\text { production }\end{array}$ & $\begin{array}{l}\text { Sex differences no } \\
\text { analyzed }\end{array}$ & $\begin{array}{l}\text { Decreased body weight and brain } \\
\text { weight, higher serum triglyceride/free } \\
\text { fatty acid, beta-hydroxy-butyrate } \\
\text { levels, decreased plasma glucose in } \\
\text { ethanol exposed pups }\end{array}$ \\
\hline & $\begin{array}{l}\text { Chen and Nyomba } \\
\text { (2004) }\end{array}$ & Rat & Not evaluated & $\begin{array}{l}\text { Male rats studied } \\
\text { exclusively }\end{array}$ & $\begin{array}{l}\text { Decreased pup birth weight, increased } \\
\text { triglycerides, insulin resistance with } \\
\text { ethanol exposure }\end{array}$ \\
\hline $\begin{array}{l}\text { Nonnutritive } \\
\text { sweeteners }\end{array}$ & Parlee et al. (2014) & Mouse & Not evaluated & $\begin{array}{l}\text { In males, decreased fat } \\
\text { mass and adipocyte } \\
\text { size, improved } \\
\text { glucose tolerance } \\
\text { with saccharin } \\
\text { lactational exposure }\end{array}$ & $\begin{array}{l}\text { Saccharin exposure was linked to } \\
\text { initial reduced body weight that } \\
\text { persisted in females }\end{array}$ \\
\hline \multirow[t]{4}{*}{$\begin{array}{l}\text { Environmental } \\
\text { toxin }\end{array}$} & Li et al. (2016) & Rat & $\begin{array}{l}\text { Bisphenol AF } \\
\text { concentration not } \\
\text { measured in milk }\end{array}$ & $\begin{array}{l}\text { Males rats studied } \\
\text { exclusively }\end{array}$ & $\begin{array}{l}\text { Bisphenol AF was transferred to pups } \\
\text { during lactation and found in the } \\
\text { testes with increased testosterone } \\
\text { levels, altered gene expression in cell } \\
\text { differentiation and meiosis. } \\
\text { Decreased body weight of male pups }\end{array}$ \\
\hline & Criswell et al. (2017) & Human & $\begin{array}{l}\text { Breast milk PCBs, } \\
\text { poly-brominated } \\
\text { diphenyl ethers, } \\
\text { organochlorine } \\
\text { pesticides, } \beta \text {-HCH } \\
\text { levels }\end{array}$ & $\begin{array}{l}\text { Results adjusted for } \\
\text { child sex }\end{array}$ & $\begin{array}{l}\text { Increased milk } \beta-\mathrm{HCH} \text { correlated with } \\
\text { reduced infant weight gain at } \\
6 \text { months }\end{array}$ \\
\hline & Pan et al. (2010) & Human & $\begin{array}{l}\text { Breast milk PCBs, } \\
\text { pesticides }\end{array}$ & $\begin{array}{l}\text { No effect after } \\
\text { co-variate analysis } \\
\text { with infant sex }\end{array}$ & $\begin{array}{l}\text { Breast milk chemical levels had no } \\
\text { impact on infant growth }\end{array}$ \\
\hline & Iszatt et al. (2015) & Human & Not evaluated & $\begin{array}{l}\text { Sex differences not } \\
\text { reported }\end{array}$ & $\begin{array}{l}\text { Postnatal PCB-153 exposure associ- } \\
\text { ated with about a } 140 \mathrm{~g} \text { weight deficit } \\
\text { at the age of } 2 \text { years compared to } \\
\text { those with lower exposures }\end{array}$ \\
\hline
\end{tabular}

ARA, arachidonic acid; $\beta-\mathrm{HCH}$, beta-hexachlorocyclohexane; DHA, docosahexaenoic acid; EPA, eicosapentaenoic acid; EFAD, essential fatty acid deficient diet; HCD, high-carbohydrate diet; HFD, high-fat diet; LCPUFA, long-chain omega-3 polyunsaturated fatty acids; PCBs, polychlorinated biphenyls; VLDL-TG, very low density lipoprotein triglyceride; BMI, body mass index; EGF, epidermal growth factor; PCB, polychlorinated biphenyl.

overfeeding (second hit) of dams during lactation increased adiposity and glucose intolerance in rat offspring of maternal obesity (first hit), providing evidence for the importance of the independent contribution of the lactational window in programming of metabolic syndrome (Chen et al. 2008).

\section{Lactational programming by early nutrient exposures}

The importance of maternal milk as a programming agent was brought to light by studies demonstrating that excessive or deficient macronutrients, as well as global undernutrition or overnutrition during the critical suckling period contribute to long-term metabolic programming. In the sections below, we address the effects of specific manipulations during the lactation period on offspring metabolic tissues.

\section{Undernutrition and overnutrition}

Animal studies have used litter size manipulation to evaluate the effects of early postnatal nutrition with crowded litters modeling the impact of undernutrition during the lactation period. These studies in mice have demonstrated reduced body fat in young male and female and geriatric male offspring (Lopez-Soldado et al. 2006, Sadagurski et al. 2014). These models also show improvements in insulin sensitivity with both sexes having decreased fasting insulin levels and improved glucose tolerance (Sadagurski et al. 2014).

Small litters have been used to understand the effects of early overnutrition and have shown that male offspring have increased weight gain and fat mass as adults but did not develop glucose intolerance until re-challenged with a high-fat diet (HFD) later in life (Glavas et al. 2010). Overnourishment during the lactational window also leads to hyperinsulinemia, impaired insulin signaling 
and impaired brown fat thermogenesis (Plagemann et al. 1992, Xiao et al 2007, Bernardo et al. 2016). In these models, male offspring have increased circulating free fatty acids, which appear to underlie impaired glucose transporter function and elevated glucose levels (Bei et al. 2015). The increased circulating fatty acids involve palmitic acid, palmitoleic acid and oleic acid, which may serve as potential biomarkers for insulin resistance (Bei et al. 2015). Importantly, these models have substantiated an independent effect of overnutrition in the perinatal period, with exposure during the lactational window leading to glucose intolerance such as that seen in pups after gestational exposure to high-fat cafeteria style diet (Rajia et al. 2010).

Nonhuman primate models of overnutrition have been characterized since the 1980s in the baboon infant (Mott \& Lewis 2009). Studies of high-calorie formula from birth to 4 months showed that overfed females developed increased fat mass and fat cell volume at 5 years of age (Lewis et al. 1989). While the female offspring had an increase in all fat depots measured, males only had increases in specific depots with no overall weight change. Potential mechanisms suggested include increased insulin responses to meals and blunted cortisol responses in young offspring (Lewis et al. 1992). The impact of overnourishment during lactation has not been well defined or studied in humans.

Overall, rodent studies of overnutrition during the lactational window show a consistent increase in offspring body weight, fat mass and insulin resistance with some of this phenotype replicated in primate studies. Interestingly, only male rodent outcomes are reported while the phenotype seems to be more prominent in female primates. Importantly, changes in milk composition were not assessed in any of the rodent models. Understanding the changes in milk composition that result from these dietary manipulations of the dam is important to understand the basis of lactational programming.

\section{Carbohydrate}

Using an artificially prepared rat milk supplement, one rat study addressed the effects of a high-carbohydrate formula. Male rats reared on this high-carbohydrate formula developed persistently elevated insulin levels and increased body weight (Aalinkeel et al. 2001). Isolated islets from the high-carbohydrate pups showed an exaggerated insulin response in vitro, a risk factor for beta cell stress (Aalinkeel et al. 2001). Pancreatic islets also had an increase in insulin content due to increased insulin biosynthesis with elevated mRNA levels for preproinsulin and transcription factors related to insulin synthesis (Srinivasan et al. 2000, 2001). The offspring also had programming of increased appetite due to hypothalamic changes, altered lipogenesis in adipose tissue and disrupted insulin signaling in the liver and skeletal muscle (Hiremagalur et al. 1993, Srinivasan et al. 2013).

A human study, while finding no significant variance in breast milk sugars (glucose, fructose and lactose) between collections at 1 and 6 months postpartum, found a direct relationship between fructose content in breast milk at 6 months and infant weight, weight for length, lean mass and fat mass at age 6 months (Goran et al. 2017). Taken together, the findings from these experimental animal and human studies stress that high early postpartum carbohydrate intake increases offspring growth trajectory and adiposity.

\section{Protein}

Animal models have shown that both high- and lowprotein diets during the early postnatal period increase susceptibility for metabolic syndrome in adulthood. A study of mouse dams on $40 \%$ high-protein diet during lactation found that their litter mass was lower than controls and this was coupled with a decrease in the dam's mammary gland mass and milk lactose (Kucia et al. 2011). In a rat model that compared pups receiving rat milk, low-protein cow's milk or high-protein cow's milk after early weaning from exclusive rat milk (postnatal day 14), female pups on the high-protein cow milk developed increased fat, hyperphagia and lower insulin secretion while males from this group had lower body protein (Rodrigues et al. 2017). This study also showed higher corticosterone levels in the highprotein cow's milk group after 1-week exposure. These results provide evidence that a high-protein diet during lactation can influence mammary gland function and milk composition, with long-term impacts on offspring growth. The difference in outcomes in these models may relate to the length of exposure. The exposure to high protein in the mouse model occurred throughout lactation, while in the rat model exposure began only at mid lactation.

Low-protein diets have been more extensively studied than high-protein diets. Maternal malnourishment using a protein-free diet during the first 10 days of lactation in rats led to increased plasma insulin levels in suckling offspring (Moura et al. 2002). Differences in insulin levels between groups subsided after weaning onto a normal diet but resurfaced when animals were re-challenged with a protein-free diet (Moura et al. 2002). Similarly, a $10 \%$ casein low-protein maternal diet during lactation decreased offspring body weight and serum glucose levels in adult males (Morimoto et al. 2012). Studies examining isolated pancreatic islets from these programmed offspring in vitro showed increased insulin secretion upon stimulation with high glucose on postnatal day 36 but impaired insulin secretory responses at 3 and 15 months (Morimoto et al. 2012). These results indicate that there may be latent programmed abnormalities that only become evident 
when an additional stressor is imposed, providing further support for the two-hit hypothesis (Tang \& Ho 2007, Padmanabhan et al. 2016).

The EU Childhood Obesity Programme, a randomized controlled trial that compared high- and low-protein formula to breast milk, found a lower BMI at 2 years of age in the low-protein-fed group while the high-proteinfed group had more rapid weight gain with increased fat mass and persistently elevated BMI at 6-year follow-up (Koletzko et al. 2009, Escribano et al. 2012, Weber et al. 2014). Overall, these results indicate that changes in early protein levels are directly related to infant growth and body weight. In addition, studies from animal models provide evidence for an impact on pancreatic beta cell function, which has not been explored in detail in human cohorts. While milk composition was not assessed in the low-protein animal models, the clinical trial results indicate that lower protein intake during the lactation period could provide an intervention strategy to alter lifelong obesity risk in offspring.

\section{Fat}

Several animal studies have shown a negative impact of HFD during lactation on infant metabolic outcome. A cross-fostering rat model evaluated offspring of rats fed a control versus HFD during gestation, which were then suckled by either control or HFD-fed dams. Male and female pups nursed by HFD dams had significantly elevated body weight, glucose intolerance, insulin resistance and elevated triglyceride and leptin levels (Masuyama \& Hiramatsu 2014). Mouse studies of dams fed a HFD during lactation showed that offspring had increased weight and fat mass, glucose homeostasis irregularities, impaired insulin secretion mediated by a decrease in parasympathetic innervation of the pancreatic beta cells and impairment in brown adipose tissue adrenergic signaling (Vogt et al. 2014, Liang et al. 2016). Cross-fostering studies have shown that HFD in the mother during suckling has an additive and independent impact on the offspring metabolic phenotype over a gestational exposure (Sun et al. 2012, Masuyama \& Hiramatsu 2014). Importantly increases in milk insulin, glucose, triglycerides and leptin have been documented in these models with the changes in insulin being directly implicated in the hypothalamic and beta cell outcomes (Vogt et al. 2014). To date, there is no available information about HFD confined to lactation in humans.

\section{Fatty acids}

The levels of certain fatty acids in milk are influenced by dietary fat exposures during lactation, and this nutrient change is carried on to the nursing pups (Oosting et al. 2015). Murine studies have shown that a maternal diet rich in long-chain omega-3 polyunsaturated fatty acids
(LCPUFAs) during lactation is associated with decreased weight, fat mass and adipocyte size in pups (Korotkova et al. 2002a, Oosting et al. 2010). Conversely, diets with an increased ratio of omega- 6 to omega-3 LCPUFAs promoted offspring weight gain and adiposity (Korotkova et al. 2002a, Hadley et al. 2017). Milk analysis in these models has identified changes that may facilitate an understanding of potential programming agents. In a mouse model of obesity during gestation and lactation, obese dams had reduced medium chain PUFA levels (Saben et al. 2014). Analysis of milk from dams fed a diet high in arachidonic acid and docosahexaenoic acid (DHA) had higher omega-6 milk content (Hadley et al. 2017), while dams given an essential fatty acid-deficient diet produced milk with increased leptin (Korotkova et al. 2002b). Rodent experiments with developmental exposures to omega-3 fatty acids have shown that they limit adipocyte hypertrophy and inflammation, while omega- 6 fatty acids stimulate adipocyte proliferation and adipogenesis (Massiera et al. 2003, Oosting et al. 2010). In a nonhuman primate macaque model of maternal long-term HFD feeding, breast milk was found to have increased insulin but lower protein, DHA and eicosopentanoic acid levels (Grant et al. 2011). Offspring of these HFD mothers had increased fat mass and decreased lean body mass.

Randomized controlled trials in human have shown that dietary interventions can increase breast milk omega-3 LCPUFAs and reduce breast milk omega- 6 to omega-3 LCPUFA ratio (Helland et al. 2008, Much et al. 2013). This has been correlated with a lower infant plasma omega-6-to-omega-3 ratio (Much et al. 2013, Sherry et al. 2015). Higher breast milk omega-3 LCPUFAs have been associated with increased skinfold thickness and BMI at 1 year (Much et al. 2013) and increased BMI at 7 years (Helland et al. 2008). The results for increased omega-6-to-omega-3 ratio have been conflicting with studies reporting a positive association with 2-month weight-for-length z-score (Panagos et al. 2016) and 4-month body fat percentage (Rudolph et al. 2017) with another study reporting a negative association with waist circumference at age 1 year (Much et al. 2013). In terms of DHA supplementation, one study using infant formula supplemented with DHA found a small negative association between DHA status at 16 weeks of age and weight at 1 and 2 years (Makrides et al. 1999). A lactation exclusive randomized controlled trial found that a 2.5-fold increase in breast milk DHA content was associated with a significantly higher $\mathrm{BMI}$ and waist circumference at 2.5 years (Lauritzen et al. 2005), but no significant anthropometric differences on follow-up at 7 years (Asserhøj et al. 2009).

Human investigations on the influence of maternal diet and maternal supplementation have confirmed that some milk fatty acids are responsive to dietary intake. In the rodent studies the impact of omega-3 supplementation on offspring weight is beneficial, 
while in primate and human studies, it seems to be detrimental or neutral depending on the specific fatty acid supplement. One limitation of the human growth outcome studies is that not all infants were exclusively breastfed. Clearly, the influence of milk fatty acids is complex in primates and warrants additional carefully controlled long-term studies with detailed milk analysis to determine the effect of changes in milk fatty acid on offspring metabolic tissues.

\section{Maternal health influences on lactation}

Maternal metabolic and nutritional status during both pregnancy and lactation has been demonstrated to influence infant outcomes. We will review the impact of maternal metabolic disease states on offspring outcomes with a focus on the effects of maternal disease on lactation and breast milk content.

\section{Maternal diabetes}

Animal models with cross-fostering have been used to study the effects of maternal diabetes exclusively during the lactational window, independent of gestational influences. For this model, control rat pups were crossfostered to one of two groups: control or streptozotocininduced diabetic dams at day 1 of birth. Offspring fostered to diabetic dams were found to have a lower growth rate than control offspring; however, adult metabolic outcomes were not studied (Fahrenkrog et al. 2004).

The effect of diabetes in humans was studied by Plagemann et al. examining a cohort of mothers with preexisting type 1 or gestational diabetes mellitus (Plagemann et al. 2002). Infants were fed either exclusively by their diabetic mother's breast milk or with a mixture of diabetic breast milk and banked donor breast milk. Infants who received exclusive breast milk from a mother with diabetes had increased infant body weight with a correlation found between increased diabetic milk intake in the first week of life and increased blood glucose levels at 2 years of age, a dose-dependent protective effect of donor milk against obesity at age 2 years (Plagemann et al. 2002). When considering the effect of breastfeeding versus formula, a study of mothers with gestational diabetes reported a decreased risk of overweight in offspring at age 5 years if mothers exclusively breastfed for more than 3 months (Schaefer-Graf et al. 2006). This protective effect was most prominent in offspring of obese mothers, indicating that breastfeeding may protect from risk of overweight in specific populations after in utero programming. A limitation of this study was that breastfeeding history was from retrospective recall.

Human studies of maternal metabolic states have also examined breast milk fat and fatty acid composition. In a study of milk from mothers with insulin-dependent diabetes, there was an overall reduction in medium chain PUFAs and reduced omega-3 PUFA derivatives thought to result from altered fatty acid metabolism (Jackson et al. 1994). An additional study demonstrated an increase in omega-6 PUFAs in the serum of mothers with a recent history of gestational diabetes (Fugmann et al. 2015). This is of interest in that a link between plasma nonesterified fatty acids and human milk fatty acid profiles has been established (Torres et al. 2006).

\section{Maternal obesity}

Over $50 \%$ of human pregnancies are complicated by maternal overweight or obesity (Gynecologists ACoOa 2013). Using an animal model to study the influence of maternal obesity, Gorski et al. used cross-fostering to compare the differences between obese and lean dams during lactation (Gorski et al. 2006). This study found that offspring from obese dams fostered to lean dams maintained an obese phenotype, but had improved insulin sensitivity compared with those fostered to obese dams. Thus, providing a lean maternal environment to offspring predisposed to an obese phenotype does not attenuate adiposity, but may provide an intervention for the development of insulin resistance. Offspring of lean dams cross-fostered to obese dams developed obesity and insulin resistance when fed a high-energy diet in adulthood. The obese dams were found to have increased insulin and altered fatty acid profiles in their milk (Gorski et al. 2006).

In a rhesus macaque model, mothers with increased weight produced milk with lower EGF levels. EGF is a bioactive factor found in human and experimental animal milk that is thought to play a role in the development of the neonatal intestine, pancreas and liver (Donovan \& Odle 1994). Higher milk EGF levels during peak lactation have also been found to be associated with increased infant body mass in males and females (Bernstein \& Hinde 2016).

While obesity limited to the lactational window is not a clinical condition that exists, increased energy intake and obesity during lactation should be viewed as exerting additional influences on long-term programming of offspring metabolism. Human studies have revealed alterations in breast milk composition in mothers with obesity. The DARLING (Davis Area Research on Lactation, Infant Nutrition and Growth) study identified that maternal body weight for height positively correlated with milk lipid concentration in healthy mothers (Nommsen et al. 1991). Milk insulin and leptin levels have also been found to be higher in the milk of mothers with overweight or obesity (Fields \& Demerath 2012, Young et al. 2017a). A significant inverse relationship between breast milk insulin levels and infant weight and lean mass was also demonstrated (Fields et al. 2017). Increasing maternal BMI has been linked to increased milk omega-6/omega-3 LCPUFA ratio 
and decreased omega-3 PUFAs (Panagos et al. 2016). Milk from obese mothers also had decreased levels of carotenoids and Vitamin D (Panagos et al. 2016). Studies have not examined exclusive lactational exposure to milk from mothers with obesity; however, a follow-up study of the offspring of the Nurses' Health Study II demonstrated a dose-dependent decrease in childhood risk of overweight with exclusive breastfeeding even in mothers with obesity (Mayer-Davis et al. 2006). Taken together, these results indicate that maternal obesity influences human breast milk composition, which in turn has the potential to influence infant growth and fat accrual. Additional longitudinal studies with glucose and insulin measures would be needed to understand long-term effects on glucose homeostasis and metabolic functioning.

\section{Maternal inflammation}

Inflammation often coexists with obesity; however, while there are studies examining the impact of inflammation during pregnancy and lactation (Segovia et al. 2015, Dudele et al. 2017), no published studies examine the effect of maternal inflammation exclusively during lactation. A mouse study examining the effects of programming from a western style diet used crossfostering to isolate the lactational impact. Maternal diet during lactation impacted the level of saturated fatty acids in the milk, which in turn increased offspring expression of inflammatory genes in the skin, intestines and liver during the suckling period (Du et al. 2012). In human studies, breast milk from obese mothers has been shown to have elevated inflammatory markers (Fields \& Demerath 2012), and a pro-inflammatory fatty acid profile that were found to be associated with infant growth and adiposity at 1 month of age (Panagos et al. 2016). Further studies of the impact of maternal inflammation during lactation on offspring metabolic outcomes and the role played by the increased inflammatory markers in the breast milk are needed, especially in mothers with metabolic disease.

\section{Maternal stressors and exposures during lactation}

In addition to nutrient exposures other maternal exposures such as stress, cigarette smoking, alcohol and environmental contaminants during the lactational window may also influence offspring metabolic phenotypes.

\section{Stress}

Postpartum maternal stress has been reported to have negative consequences for lactogenesis and lactation duration (Dewey 2001, Lau 2001). A stress response may result in altered hormone production. One impact is on glucocorticoids, which not only play a role in the stress response, but also in mammary gland development, lactogenesis and in milk production. Cortisol and cortisone are present in milk and are transferred to the neonate through absorption by the intestinal epithelium leading to gut maturation and through the intestinal barrier into the offspring blood stream leading to systemic effects (Macrì et al. 2011, Hinde et al. 2015, Hollanders et al. 2017). Studies on the level of glucocorticoids in breast milk and their relationship to infant metabolic outcomes during the lactational window in animal and human models show inconsistent results potentially related to the difficulty of sampling and variations in analytical techniques (Pundir et al. 2017).

In a red squirrel model of exposure to high-density cues to induce physiological stress while rearing litter, female squirrels had increased glucocorticoids and their offspring had an accelerated postnatal growth rate (Dantzer et al. 2013). A study of the rhesus macaque evaluated glucocorticoid levels in breast milk and their influence on offspring temperament and growth and found breast milk cortisol levels were positively associated with infant weight gain (Hinde et al. 2015).

Human studies of stress are more complicated, as a single stress is difficult to isolate from compounded factors (Dozier et al. 2012). These stressors not only influence maternal health, but may also have an impact on breast milk composition (Kondo et al. 2011) and childhood development (Lau 2001). In a small prospective study of childhood BMI percentiles over 2 years in relation to maternal breast milk cortisol level at 3 months, increased cortisol levels were associated with lower BMI percentile at age 2 years and decreased rapid early BMI gain in girls (Hahn-Holbrook et al. 2016). In a study of preterm deliveries, a time where increased maternal stress is expected, higher cortisone levels were found in breast milk when delivery was after 30 weeks compared to earlier gestation delivery but infant metabolic outcomes were not measured (Pundir et al. 2018). Additional human studies would need to be performed to further understand the impact of breast milk glucocorticoid levels on infant growth outcomes and metabolic programming mechanisms, given these conflicting results.

\section{Smoking}

Maternal smoking and nicotine exposure during pregnancy have been linked to several negative fetal hormone and metabolic outcomes (Tweed et al. 2012). However, many women who smoke may quit during pregnancy but resume after delivery (Rockhill et al. 2016, Logan et al. 2017). Smoking relapse after birth may program for adverse metabolic outcomes independent of programming in the gestational period. Studies have confirmed that nicotine does transfer into human breast milk, even if smoking occurs in a separate environment (Santos-Silva et al. 2011). During lactation, offspring are 
exposed to nicotine directly through mother's milk as well as indirectly through environmental exposure as second hand or passive smoke exposure. Both methods have been independently evaluated (de Oliveira et al. 2010, Santos-Silva et al. 2013) to determine offspring metabolic outcomes.

In the direct model of nicotine exposure, nicotine is infused into dams during lactation to simulate the blood nicotine levels seen in average human smokers. While offspring have a lower concentration of blood nicotine than dams, they have a much higher concentration of nicotine than control pups. When these offspring are examined as adults, offspring exposed to nicotine show significantly increased body weight, whole body and visceral adiposity and fasting insulin levels compared to controls (de Oliveira et al. 2010). In the indirect model of nicotine exposure, mother and offspring are placed in a smoking chamber to simulate the effects of environmental tobacco smoke exposure. At weaning, blood nicotine levels were elevated in offspring exposed to tobacco smoke, while blood insulin levels were significantly lower than controls. As adults, offspring exposed to tobacco smoke showed a significantly higher total body fat than controls. Unlike the direct model findings, second hand exposed rats were found to have hyperglycemia with normal insulin levels in adulthood (Santos-Silva et al. 2013). While there are no human data to reflect the impact of smoking during the lactation period alone, studies of infant feeding and growth have revealed a negative association between maternal smoking and infant linear growth (Makrides et al. 1999), although an association with long-term metabolic disease is less clear.

\footnotetext{
Alcohol

Gestational consumption of alcohol may lead to deleterious effects on neonates, including the development of metabolic syndrome (Tavares do Carmo et al. 1999, Murillo-Fuentes et al. 2003, Ting \& Lautt 2006). Studies focused on maternal postnatal consumption of alcohol and infant metabolic outcomes, however, are rare. Chen and Nyomba compared the results of prenatal and postnatal maternal alcohol abuse using rats to model mothers who resume heavy alcohol consumption during lactation (Chen \& Nyomba 2004). At 16 weeks of age, male offspring had higher glucose responses on glucose tolerance tests than controls, similar to offspring with prenatal ethanol exposure (Chen \& Nyomba 2004). The postnatal ethanolexposed animals also had decreased insulin sensitivity similar to the prenatal exposure group. Given the outcomes demonstrated in these limited animal studies, clinical interventions to limit maternal smoking and alcohol consumption may need to be extended to the lactation period.
}

\section{Nonnutritive sweeteners}

Artificial sweeteners have become commonplace in western food and drink as a substitute for sugar. In an animal model of nonnutritive sweetener exposure during lactation, female lactating mice were exposed to saccharin in water for 21 days after birth (Parlee et al. 2014). In this study, female offspring experienced decreased weight gain that emerged during the third postnatal week, while male offspring showed increased body weight with age. In adulthood, male saccharin exposed offspring showed decreased fat mass and increased lean mass, with changes in visceral adipocyte size; however, female mice did not follow this pattern (Parlee et al. 2014).

In a human study of nonnutritive sweetener consumption during lactation, Sylvetsky et al. (2015) found that saccharin, sucralose and acesulfame potassium, but not aspartame, were all detected in human breast milk. However, further research is needed to understand the impact of these nonnutritive sweeteners on long-term metabolic outcomes in the offspring.

\section{Environmental toxins}

It is becoming increasingly clear that developmental exposures to environmental contaminants have lasting effects on metabolic tissues and have endocrine disrupting potential (Heindel et al. 2017). Studies have documented the presence of environmental toxins in breast milk thus introducing the possibility of lactational programming (Solomon \& Weiss 2002). Chemicals that persist in the environment even after regulation to ban them are concerning if they are lipophilic, as they are likely to accumulate in the adipose tissue over time. Indeed, higher levels are thought to reach breast-fed infants than would be accounted for by daily exposure, an aspect reviewed by Lehmann et al. (2014). A study of 633 women found breast milk to be a route of exposure to perfluoroalkyl acids in breast-fed infants (Mondal et al. 2014). In another study measuring 121 endocrine disrupting chemicals in breast milk, a higher prevalence of persistent chemicals were found in samples obtained in Denmark compared to those obtained in Finland (Krysiak-Baltyn et al. 2010). To what extent countryspecific differences in lactational exposure to persistent organic chemicals are associated with differences in metabolic health, such as that reported for testicular cancers (Skakkebaek et al. 2007, Krysiak-Baltyn et al. 2010, Antignac et al. 2016) remains to be determined.

Studies addressing the impact of exposure to environmental chemicals exclusively during the lactational window are sparse. Most studies testing the impact of exposure to environmental chemicals have focused on the perinatal window. In these studies it is difficult to distinguish the effects of gestational impact from lactational impact. In one cross-fostering study, 
Bisphenol AF administered to rats only during the postnatal window was found to transfer thorough breast milk to the offspring and decrease the growth of male pups during suckling (Li et al. 2016). When considering the impact of polychlorinated biphenyls (PCBs), trends found between human breast milk PCB concentrations and infant growth outcomes are conflicting. One study showed a correlation between increased breast milk levels of beta-hexachlorocyclohexane $(\beta-\mathrm{HCH})$, an agricultural pesticide, at 1 month after birth and reduced infant weight gain up to age 6 months (Criswell et al. 2017). However, another found no significant difference between infant growth measures at 6 months and 1 year and increased PCBs in human milk at 3 months postpartum (Pan et al. 2010). A large analysis of multiple European birth cohorts demonstrated a negative association between postnatal PCB-153 exposure and change in infant weight for age z-score from birth to 24 months (Iszatt et al. 2015). This field of research centering on the impact of lactational exposure to endocrine disrupting chemicals is beginning to expand and presents an opportunity to investigate the long-term metabolic consequences from such exposures.

\section{Mechanisms of lactational programming}

Molecular mechanisms at the level of offspring tissue identified in lactational programming experiments include oxidative stress, inflammation, methylation changes, histone modifications and altered axonal migration (Fig. 2), similar to mechanisms identified in in utero programming (Berends \& Ozanne 2012). While the specific mediators of these changes are not known, alterations in the levels and actions of hormones present in the milk, including insulin, leptin and cortisol have been implicated (Badillo-Suárez et al. 2017) along with altered breast milk microRNA levels (Munch et al. 2013). Exposure to excessive nutrients during lactation has been shown to induce oxidative stress and increase reactive oxygen species in the livers of male rat offspring (Conceicao et al. 2013). In this rat model of postnatal overfeeding there were higher levels of malondialdehyde, a marker of oxidative stress and reduced levels of antioxidants including catalase, superoxide dismutase and glutathione peroxidase in the livers of male offspring (Conceicao et al. 2013). Reactive oxygen species have been linked to attenuated insulin signaling, particularly in the liver in rodent

\section{MATERNAL STATE}

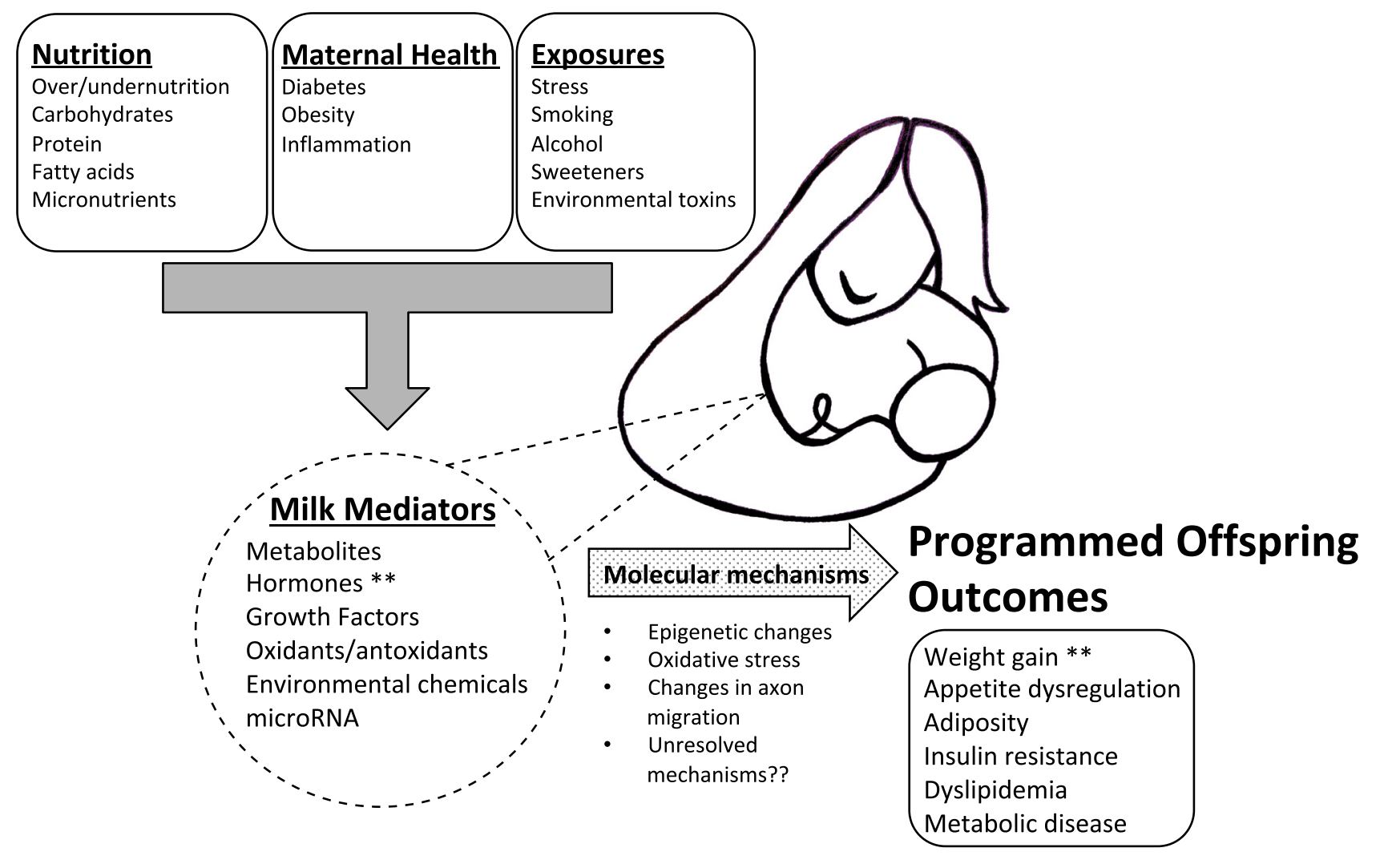

** Increased milk insulin in dams fed a high fat diet mediates impaired glucose tolerance and an obese phenotype in offspring (Vogt et al. 2014)

Figure 2 Proposed mechanisms of developmental programming during the lactation period. Copyright Gregg Lab, reproduced with permission. 
models (Hirosumi et al. 2002, Conceicao et al. 2013). Elevations in milk reactive oxygen species have also been linked positively with infant weight-for-length z-score up to age 6 months (Young et al. 2017b). Epigenetic changes may occur in response to postnatal nutritional influences, leading to programming. Longer duration of breastfeeding in humans has been linked with global methylation changes, along with methylation changes of promoters for genes important for metabolic homeostasis (Hartwig et al. 2017). For instance, longer duration of breastfeeding was found to be associated with a decrease in leptin promoter methylation in human blood samples of 17-month-old babies (Obermann-Borst et al. 2013). Neonatal feeding of high-carbohydrate formula increased hypothalamic neuropeptide $Y$ (an orexigenic neuropeptide) mRNA expression, decreased promoter methylation at several CpG sites and increased histone acetylation in female rat offspring (Mahmood et al. 2013). This same group also demonstrated a decrease in skeletal muscle Glut4 transporter mRNA in adult male offspring from the high-carbohydrate group. This decrease in Glut4 transporter mRNA was accompanied by an increase in Slc2a4 (encoding insulin-related glucose transporter 4) promoter methylation (Raychaudhuri et al. 2014). Another component of breast milk involved in regulation of gene expression is microRNA. These small noncoding RNAs are thought to transfer undigested from human milk into the infant blood stream (Kosaka et al. 2010, Alsaweed et al. 2015). Some of the specific species of microRNAs detected in human breast milk are altered in response to maternal HFD during lactation (Munch et al. 2013). It is important to note that changes in the milk likely lead to the deleterious responses in offspring tissues, but more work needs to be done to understand the specific mediators of these effects.

\section{Interventions during the window of lactation}

Interventions during the critical periods of infant development, like the lactational window, offer a key area for future research to identify potential strategies to target long-term metabolic risk prevention. Current intervention work has focused on the areas of calorie restriction, exercise intervention, and nutritional supplementation.

\section{Maternal exercise during lactation}

Maternal exercise during the lactation period has numerous physiological benefits for both mother and baby (Bane 2015). However, most of the research has focused on maternal postpartum metabolic health (Dewey et al. 1994, Lovelady et al. 2000) rather than on infant outcomes from maternal exercise. A perinatal study by Ribeiro et al. provides a preliminary insight into the metabolic benefits of maternal perinatal exercise
(Ribeiro et al. 2017). Using an animal model, this study evaluated the effects of maternal low-intensity exercise during both pregnancy and lactation and postnatal overnutrition on adult male offspring metabolic outcomes (Ribeiro et al. 2017). In both normal litter and small litter (overnutrition) offspring of exercised dams, a reduction in fasting insulin and a decrease in adiposity were observed compared to both normal litter and small litter offspring of sedentary dams. Human studies of the effect of exercise interventions on milk composition and offspring metabolic health could provide more valuable evidence in this area.

\section{Offspring dietary changes and supplementation}

Studies examining dietary interventions during the lactational window are few. Postnatal dietary interventions during the suckling period may offer a method to realign metabolic abnormalities developed as a neonate. The limited number of available intervention studies do not yet support human applications. Prebiotic fiber offers one form of dietary modification that has been linked with a reduction in body fat and glucose levels (Reid et al. 2016). We found no animal or human clinical studies that focus exclusively on probiotic intervention during the lactational window and offspring metabolic outcomes. However, Luoto et al. looked at probiotic supplementation (Lactobacillus rhamnosus) during the perinatal period, from 4 weeks before birth to 6 months postpartum (Luoto et al. 2010). At 4 years of age, children perinatally supplemented with probiotics showed a trend to reduced BMI (Luoto et al. 2010). These results suggest potential for a dietary supplement to be beneficial for metabolic health and highlight the need for further investigation of such supplements during the lactation period.

\section{Non-dietary interventions}

Since milk bioactive factors are thought to play a role in programming, investigations into bioactive factor supplements as interventions to prevent metabolic disease have been undertaken. Leptin supplementation offers one such potential intervention during suckling, given its roles in central appetite and energy regulation and adipogenesis. Leptin is present in breast milk but not in commercial formulas and has been proposed to result in signals of satiety in newborns (Badillo-Suárez et al. 2017). A human study examining Filipino women showed higher milk leptin in mothers with increased body fat and an inverse relation between milk leptin levels infant weight and BMI at 1 year of age (Quinn et al. 2015). Patterson et al. found that large litter rearing decreased circulating leptin levels by the second postnatal day and reduced weight gain by postnatal day 8 in male and female pups of diet-induced obese rats (Patterson et al. 2010). In a rat model of neonatal 
supplementation with oral leptin, long-term outcomes included lower body weight in adulthood and improved insulin sensitivity in male offspring (Sánchez et al. 2008). When leptin was provided as an oral intervention in a rat model of HFD, male offspring had improved body weight, lower leptin receptor abundance in adipose tissue, increased expression of genes involved in fat oxidation and lipogenesis, along with decreased liver fat accumulation (Picó et al. 2007, Priego et al. 2010). When leptin was supplemented subcutaneously to pups in a model of maternal undernutrition, there was decreased weight gain in pups and normalized glucose, insulin and leptin concentrations compared to pups not receiving supplementation (Vickers et al. 2005). GLP-1, an incretin hormone, plays a role in glucose homeostasis by increasing beta cell insulin secretion as well as promotes satiety via hypothalamic actions (Badillo-Suárez et al. 2017). Animal models of early postnatal intervention with GLP-1 receptor agonists have demonstrated decreased adipose tissue and improvements in glucose tolerance and liver insulin sensitivity in mouse (male and female), rat (male) and sheep (sex not reported) models (Raab et al. 2009, Gatford et al. 2013, Rozo et al. 2017). Further work is needed in order to better characterize benefits vs risks in order to consider translation of these findings from animal models into human studies.

\section{Conclusions}

Despite the broad range of exposures covered in this review, common outcomes of early stressors during the lactational window are programming of insulin responsiveness in insulin sensitive tissues; feeding behavior via changes in hypothalamic circuits and leptin action; adipocyte number and specific adipose depot expansion and pancreatic beta cell glucose responsiveness. Animal models of macronutrient excess or global overnutrition during the lactational window lead to dramatic $10-40 \%$ increases in offspring body weight often with increases in visceral fat, while findings in large human intervention trials revealed more modest impacts on weight, weight for length, waist circumference or BMI. Other common patterns that emerge from these studies are the occurrence of physiologic changes during the exposure, which then seem to resolve only to be unmasked when a second stressor is applied later in life. Additionally, in rodent models of lactational programming the phenotype is often more severe in male offspring whereas the primate females tend to have stronger metabolic perturbations. Finally, these studies have demonstrated that there is indeed an independent contribution of the lactation period to long-term metabolic health and that the impact of lactational stressors can be as significant as an in utero stressor.
With the rising incidence of obesity, diabetes and hypertension, understanding the windows of susceptibility that contribute to developmental programming are vital to identify important time periods to target intervention strategies. The lactational window has been shown to be a critical window for establishment of body composition, insulin sensitivity and beta cell mass accrual and is a period of greater plasticity of metabolic tissues than later in life. In addition, the lactation period offers a time for intervention such that gestational insults may be ameliorated in offspring at risk for poor metabolic outcomes. The programming influences of altered breast milk nutrient, hormone and bioactive factor composition, maternal health and environmental toxin exposures are an area that is only beginning to unravel. Breast milk research is made more complex because milk composition has been shown to change over time, as well as with maternal age, parity, multiple births and infant gender in animal and human studies (Michaelsen et al. 1994, Hinde 2009, Hinde et al. 2009, Powe et al. 2010, Thakkar et al. 2013). Significant future research with a focus on the lactational window is necessary to understand specific mechanisms that change offspring metabolic trajectory taking into account the complex maternal influences on breast milk.

Of the studies reviewed, few examine a specific lactational stressor with detailed milk composition studies and long-term offspring metabolic phenotyping. Animal studies offer the opportunity to address this gap and pinpoint mediators of programmed outcomes to isolate milk changes, rather than changes in bonding, as causative factors. Animal models are not a perfect proxy for human lactation given variations in organ developmental time frames, plasticity and capacity to buffer deleterious exposures, therefore, further large human cohort studies are also needed to understand the short- and long-term impacts of lactational stressors. Such studies could identify biomarkers of metabolic outcomes with the goal of eventually targeting interventions to the lactational window and develop clinical recommendations to advise lactating mothers. While breast milk has extensive benefits to the newborn that cannot be undervalued, a greater understanding of the influence of altered milk composition could allow for early maternal lifestyle interventions and infant personalized nutrition interventions to optimize longterm metabolic health.

\section{Declaration of interest}

The authors declare that there is no conflict of interest that could be perceived as prejudicing the impartiality of this review.

\section{Funding}

This research did not receive any specific grant from any funding agency in the public, commercial or not-for-profit sector. 


\section{Acknowledgements}

The authors would like to thank Marisa Conte, an Informationist at UMHS Taubman Library, for helping us to achieve an expansive and thorough literature search.

\section{References}

Aalinkeel R, Srinivasan M, Song F \& Patel MS 2001 Programming into adulthood of islet adaptations induced by early nutritional intervention in the rat. American Journal of Physiology: Endocrinology and Metabolism 281 E640-E648. (https://doi.org/10.1152/ ajpendo.2001.281.3.E640)

Alsaweed M, Hartmann PE, Geddes DT \& Kakulas F 2015 MicroRNAs in breastmilk and the lactating breast: potential immunoprotectors and developmental regulators for the infant and the mother. International Journal of Environmental Research and Public Health 12 13981-14020. (https://doi.org/10.3390/ijerph121113981)

Antignac JP, Main KM, Virtanen HE, Boquien CY, Marchand P, Venisseau A, Guiffard I, Bichon E, Wohlfahrt-Veje C, Legrand A et al. 2016 Countryspecific chemical signatures of persistent organic pollutants (POPs) in breast milk of French, Danish and Finnish women. Environmental Pollution 218 728-738. (https://doi.org/10.1016/j.envpol.2016.07.069)

Asserhøj M, Nehammer S, Matthiessen J, Michaelsen KF \& Lauritzen L 2009 Maternal fish oil supplementation during lactation may adversely affect long-term blood pressure, energy intake, and physical activity of 7-year-old boys. Journal of Nutrition 139 298-304. (https://doi. org/10.3945/jn.108.095745)

Badillo-Suárez PA, Rodríguez-Cruz M \& Nieves-Morales X 2017 Impact of metabolic hormones secreted in human breast milk on nutritional programming in childhood obesity. Journal of Mammary Gland Biology and Neoplasia 22 171-191. (https://doi.org/10.1007/s10911-0179382-y)

Bane SM 2015 Postpartum exercise and lactation. Clinical Obstetrics and Gynecology 58 885-892. (https://doi.org/10.1097/ GRF.0000000000000143)

Barker DJ, Winter PD, Osmond C, Margetts B \& Simmonds SJ 1989 Weight in infancy and death from ischaemic heart disease. Lancet 2 577-580. (https://doi.org/10.1016/S0140-6736(89)90710-1)

Bartol FF, Wiley AA \& Bagnell CA 2008 Epigenetic programming of porcine endometrial function and the lactocrine hypothesis. Reproduction in Domestic Animals 43 (Supplement) 273-279. (https://doi.org/10.1111/ j.1439-0531.2008.01174.x)

Bartol FF, Wiley AA, Miller DJ, Silva AJ, Roberts KE, Davolt ML, Chen JC, Frankshun AL, Camp ME, Rahman KM et al. 2013 Lactation Biology Symposium: lactocrine signaling and developmental programming. Journal of Animal Science 91 696-705. (https://doi.org/10.2527/ jas.2012-5764)

Beath SV 2003 Hepatic function and physiology in the newborn. Seminars in Neonatology 8 337-346. (https://doi.org/10.1016/S10842756(03)00066-6)

Bei F, Jia J, Jia YQ, Sun JH, Liang F, Yu ZY \& Cai W 2015 Long-term effect of early postnatal overnutrition on insulin resistance and serum fatty acid profiles in male rats. Lipids in Health and Disease 14 96. (https://doi. org/10.1186/s12944-015-0094-2)

Berends LM \& Ozanne SE 2012 Early determinants of type-2 diabetes. Best Practice and Research: Clinical Endocrinology and Metabolism 26 569-580. (https://doi.org/10.1016/j.beem.2012.03.002)

Bernardo AF, Cortez E, Neves FA, Vieira AK, Soares VeM, RodriguesCunha AC, Andrade DC, Thole AA, Gabriel-Costa D, Brum PC et al. 2016 Overnutrition during lactation leads to impairment in insulin signaling, up-regulation of GLUT1 and increased mitochondrial carbohydrate oxidation in heart of weaned mice. Journal of Nutritional Biochemistry 29 124-132. (https://doi.org/10.1016/j.jnutbio.2015.09.021)

Bernstein RM \& Hinde K 2016 Bioactive factors in milk across lactation: maternal effects and influence on infant growth in rhesus macaques (Macaca mulatta). American Journal of Primatology 78 838-850. (https:// doi.org/10.1002/ajp.22544)

Bonner-Weir S 2000 Life and death of the pancreatic beta cells. Trends in Endocrinology and Metabolism 11 375-378. (https://doi.org/10.1016/ S1043-2760(00)00305-2)
Cerf ME, Chapman CS \& Louw J 2012 High-fat programming of hyperglycemia, hyperinsulinemia, insulin resistance, hyperleptinemia, and altered islet architecture in 3-month-old wistar rats. ISRN Endocrinology 2012 627270. (https://doi.org/10.5402/2012/627270)

Chen L \& Nyomba BL 2004 Whole body insulin resistance in rat offspring of mothers consuming alcohol during pregnancy or lactation: comparing prenatal and postnatal exposure. Journal of Applied Physiology 96 167-172. (https://doi.org/10.1152/japplphysiol.00751.2003)

Chen H, Simar D, Lambert K, Mercier J \& Morris MJ 2008 Maternal and postnatal overnutrition differentially impact appetite regulators and fuel metabolism. Endocrinology 149 5348-5356. (https://doi.org/10.1210/ en.2008-0582)

Conceicao EP, Franco JG, Oliveira E, Resende AC, Amaral TA, PeixotoSilva N, Passos MC, Moura EG \& Lisboa PC 2013 Oxidative stress programming in a rat model of postnatal early overnutrition - role of insulin resistance. Journal of Nutritional Biochemistry 24 81-87. (https:// doi.org/10.1016/j.jnutbio.2012.02.010)

Criswell R, Lenters V, Mandal S, Stigum H, Iszatt N \& Eggesbø M 2017 Persistent environmental toxicants in breast milk and rapid infant growth. Annals of Nutrition and Metabolism 70 210-216. (https://doi. org/10.1159/000463394)

Dantzer B, Newman AE, Boonstra R, Palme R, Boutin S, Humphries MM \& McAdam AG 2013 Density triggers maternal hormones that increase adaptive offspring growth in a wild mammal. Science 340 1215-1217. (https://doi.org/10.1126/science.1235765)

de Oliveira E, Moura EG, Santos-Silva AP, Pinheiro CR, Lima NS, NogueiraNeto JF, Nunes-Freitas AL, Abreu-Villaça Y, Passos MC \& Lisboa PC 2010 Neonatal nicotine exposure causes insulin and leptin resistance and inhibits hypothalamic leptin signaling in adult rat offspring. Journal of Endocrinology 206 55-63. (https://doi.org/10.1677/JOE-10-0104)

Devaskar SU \& Thamotharan M 2007 Metabolic programming in the pathogenesis of insulin resistance. Reviews in Endocrine and Metabolic Disorders 8 105-113. (https://doi.org/10.1007/s11154-007-9050-4)

Dewey KG 2001 Maternal and fetal stress are associated with impaired lactogenesis in humans. Journal of Nutrition 131 3012S-3015S. (https:// doi.org/10.1093/jn/131.11.3012S)

Dewey KG, Lovelady CA, Nommsen-Rivers LA, McCrory MA \& Lönnerdal B 1994 A randomized study of the effects of aerobic exercise by lactating women on breast-milk volume and composition. New England Journal of Medicine 330 449-453. (https://doi.org/10.1056/ NEJM199402173300701)

Donovan SM \& Odle J 1994 Growth factors in milk as mediators of infant development. Annual Review of Nutrition 14 147-167. (https://doi. org/10.1146/annurev.nu.14.070194.001051)

Dozier AM, Nelson A \& Brownell E 2012 The relationship between life stress and breastfeeding outcomes among low-income mothers. Advances in Preventive Medicine 2012 902487. (https://doi. org/10.1155/2012/902487)

Du Y, Yang M, Lee S, Behrendt CL, Hooper LV, Saghatelian A \& Wan Y 2012 Maternal western diet causes inflammatory milk and TLR2/4dependent neonatal toxicity. Genes and Development 26 1306-1311. (https://doi.org/10.1101/gad.191031.112)

Dudele A, Hougaard KS, Kjølby M, Hokland M, Winther G, Elfving B, Wegener G, Nielsen AL, Larsen A, Nøhr MK et al. 2017 Chronic maternal inflammation or high-fat-feeding programs offspring obesity in a sex-dependent manner. International Journal of Obesity $\mathbf{4 1}$ 1420-1426. (https://doi.org/10.1038/ijo.2017.136)

Escribano J, Luque V, Ferre N, Mendez-Riera G, Koletzko B, Grote V, Demmelmair H, Bluck L, Wright A, Closa-Monasterolo R et al. 2012 Effect of protein intake and weight gain velocity on body fat mass at 6 months of age: the EU Childhood Obesity Programme. International Journal of Obesity 36 548-553. (https://doi.org/10.1038/ijo.2011.276)

Fahrenkrog S, Harder T, Stolaczyk E, Melchior K, Franke K, Dudenhausen JW \& Plagemann A 2004 Cross-fostering to diabetic rat dams affects early development of mediobasal hypothalamic nuclei regulating food intake, body weight, and metabolism. Journal of Nutrition 134 648-654. (https:// doi.org/10.1093/jn/134.3.648)

Feng B, Zhang T \& Xu H 2013 Human adipose dynamics and metabolic health. Annals of the New York Academy of Sciences 1281 160-177. (https://doi.org/10.1111/nyas.12009)

Fields DA \& Demerath EW 2012 Relationship of insulin, glucose, leptin, IL-6 and TNF-alpha in human breast milk with infant growth and body 
composition. Pediatric Obesity 7 304-312. (https://doi.org/10.1111/ j.2047-6310.2012.00059.x)

Fields DA, George B, Williams M, Whitaker K, Allison DB, Teague A \& Demerath EW 2017 Associations between human breast milk hormones and adipocytokines and infant growth and body composition in the first 6 months of life. Pediatric Obesity 12 (Supplement) 78-85. (https://doi. org/10.1111/ijpo.12182)

Frankshun AL, Ho TY, Reimer DC, Chen J, Lasano S, Steinetz BG, Bartol FF \& Bagnell CA 2011 Characterization and biological activity of relaxin in porcine milk. Reproduction 141 373-380. (https://doi.org/10.1530/ REP-10-0401)

Fugmann M, Uhl O, Hellmuth C, Hetterich H, Kammer NN, Ferrari U, Parhofer KG, Koletzko B, Seissler J \& Lechner A 2015 Differences in the serum nonesterified fatty acid profile of young women associated with a recent history of gestational diabetes and overweight/obesity. PLOS ONE 10 e0128001. (https://doi.org/10.1371/journal.pone.0128001)

Gatford KL, Sulaiman SA, Mohammad SN, De Blasio MJ, Harland ML, Simmons RA \& Owens JA 2013 Neonatal exendin-4 reduces growth, fat deposition and glucose tolerance during treatment in the intrauterine growth-restricted lamb. PLOS ONE 8 e56553. (https://doi.org/10.1371/ journal.pone.0056553)

Glavas MM, Kirigiti MA, Xiao XQ, Enriori PJ, Fisher SK, Evans AE, Grayson BE, Cowley MA, Smith MS \& Grove KL 2010 Early overnutrition results in early-onset arcuate leptin resistance and increased sensitivity to high-fat diet. Endocrinology 151 1598-1610. (https://doi.org/10.1210/ en.2009-1295)

Gluckman PD, Hanson MA, Cooper C \& Thornburg KL 2008 Effect of in utero and early-life conditions on adult health and disease. New England Journal of Medicine 359 61-73. (https://doi.org/10.1056/ NEJMra0708473)

Goran MI, Martin AA, Alderete TL, Fujiwara H \& Fields DA 2017 Fructose in breast milk is positively associated with infant body composition at 6 months of age. Nutrients 9 E146. (https://doi.org/10.3390/nu9020146)

Gorski JN, Dunn-Meynell AA, Hartman TG \& Levin BE 2006 Postnatal environment overrides genetic and prenatal factors influencing offspring obesity and insulin resistance. American Journal of Physiology: Regulatory Integrative and Comparative Physiology 291 R768-R778. (https://doi.org/10.1152/ajpregu.00138.2006)

Grant WF, Gillingham MB, Batra AK, Fewkes NM, Comstock SM, Takahashi D, Braun TP, Grove KL, Friedman JE \& Marks DL 2011 Maternal high fat diet is associated with decreased plasma n-3 fatty acids and fetal hepatic apoptosis in nonhuman primates. PLOS ONE 6 e17261. (https://doi.org/10.1371/journal.pone.0017261)

Gynecologists ACoOa 2013 ACOG Committee opinion no. 549: obesity in pregnancy. Obstetrics and Gynecology 121 213-217. (https://doi. org/10.1097/01.AOG.0000425667.10377.60)

Hadley KB, Guimont-Desrochers F, Bailey-Hall E, Salem N, YurkoMauro K \& Field CJ 2017 Supplementing dams with both arachidonic and docosahexaenoic acid has beneficial effects on growth and immune development. Prostaglandins, Leukotrienes and Essential Fatty Acids 126 55-63. (https://doi.org/10.1016/j.plefa.2017.09.002)

Hahn-Holbrook J, Le TB, Chung A, Davis EP \& Glynn LM 2016 Cortisol in human milk predicts child BMI. Obesity 24 2471-2474. (https://doi. org/10.1002/oby.21682)

Hartwig FP, Loret de Mola C, Davies NM, Victora CG \& Relton CL 2017 Breastfeeding effects on DNA methylation in the offspring: a systematic literature review. PLOS ONE 12 e0173070. (https://doi.org/10.1371/ journal.pone.0173070)

Heindel JJ, Blumberg B, Cave M, Machtinger R, Mantovani A, Mendez MA, Nadal A, Palanza P, Panzica G, Sargis R et al. 2017 Metabolism disrupting chemicals and metabolic disorders. Reproductive Toxicology 68 3-33. (https://doi.org/10.1016/j.reprotox.2016.10.001)

Helland IB, Smith L, Blomén B, Saarem K, Saugstad OD \& Drevon CA 2008 Effect of supplementing pregnant and lactating mothers with $\mathrm{n}-3$ very-long-chain fatty acids on children's IQ and body mass index at 7 years of age. Pediatrics 122 e472-e479. (https://doi.org/10.1542/ peds.2007-2762)

Hicks M \& Pyle A 2015 The path from pluripotency to skeletal muscle: developmental myogenesis guides the way. Cell Stem Cell 17 255-257. (https://doi.org/10.1016/j.stem.2015.08.017)

Hinde K 2009 Richer milk for sons but more milk for daughters: sex-biased investment during lactation varies with maternal life history in rhesus macaques. American Journal of Human Biology 21 512-519. (https:// doi.org/10.1002/ajhb.20917)

Hinde K \& Capitanio JP 2010 Lactational programming? Mother's milk energy predicts infant behavior and temperament in rhesus macaques (Macaca mulatta). American Journal of Primatology 72 522-529. (https:// doi.org/10.1002/ajp.20806)

Hinde K, Power ML \& Oftedal OT 2009 Rhesus macaque milk: magnitude, sources, and consequences of individual variation over lactation. American Journal of Physical Anthropology 138 148-157. (https://doi. org/10.1002/ajpa.20911)

Hinde K, Skibiel AL, Foster AB, Del Rosso L, Mendoza SP \& Capitanio JP 2015 Cortisol in mother's milk across lactation reflects maternal life history and predicts infant temperament. Behavioral Ecology 26 269-281. (https://doi.org/10.1093/beheco/aru186)

Hiremagalur BK, Vadlamudi S, Johanning GL \& Patel MS 1993 Longterm effects of feeding high carbohydrate diet in pre-weaning period by gastrostomy: a new rat model for obesity. International Journal of Obesity and Related Metabolic Disorders 17 495-502.

Hirosumi J, Tuncman G, Chang L, Görgün CZ, Uysal KT, Maeda K, Karin M \& Hotamisligil GS 2002 A central role for JNK in obesity and insulin resistance. Nature 420 333-336. (https://doi.org/10.1038/nature01137)

Hollanders JJ, Heijboer AC, van der Voorn B, Rotteveel J \& Finken MJJ 2017 Nutritional programming by glucocorticoids in breast milk: targets, mechanisms and possible implications. Best Practice and Research: Clinical Endocrinology and Metabolism 31 397-408. (https://doi. org/10.1016/j.beem.2017.10.001)

Iszatt N, Stigum H, Verner MA, White RA, Govarts E, Murinova LP, Schoeters G, Trnovec T, Legler J, Pelé F et al. 2015 Prenatal and postnatal exposure to persistent organic pollutants and infant growth: a pooled analysis of seven European birth cohorts. Environmental Health Perspectives 123 730-736. (https://doi.org/10.1289/ehp.1308005)

Jackson MB, Lammi-Keefe CJ, Jensen RG, Couch SC \& Ferris AM 1994 Total lipid and fatty acid composition of milk from women with and without insulin-dependent diabetes mellitus. American Journal of Clinical Nutrition $60353-361$. (https://doi.org/10.1093/ajcn/60.3.353)

Koletzko B, von Kries R, Closa R, Escribano J, Scaglioni S, Giovannini M, Beyer J, Demmelmair H, Gruszfeld D, Dobrzanska A et al. 2009 Lower protein in infant formula is associated with lower weight up to age $2 \mathrm{y}$ : a randomized clinical trial. American Journal of Clinical Nutrition 89 1836-1845. (https://doi.org/10.3945/ajcn.2008.27091)

Kondo N, Suda Y, Nakao A, Oh-Oka K, Suzuki K, Ishimaru K, Sato M, Tanaka T, Nagai A \& Yamagata Z 2011 Maternal psychosocial factors determining the concentrations of transforming growth factor-beta in breast milk. Pediatric Allergy and Immunology 22 853-861. (https://doi. org/10.1111/j.1399-3038.2011.01194.x)

Korotkova M, Gabrielsson B, Hanson LA \& Strandvik B 2002a Maternal dietary intake of essential fatty acids affects adipose tissue growth and leptin mRNA expression in suckling rat pups. Pediatric Research 52 78-84. (https://doi.org/10.1203/00006450-200207000-00015)

Korotkova M, Gabrielsson B, Lonn M, Hanson LA \& Strandvik B 2002b Leptin levels in rat offspring are modified by the ratio of linoleic to alpha-linolenic acid in the maternal diet. Journal of Lipid Research $\mathbf{4 3}$ 1743-1749. (https://doi.org/10.1194/jlr.M200105-JLR200)

Kosaka N, Izumi H, Sekine K \& Ochiya T 2010 microRNA as a new immune-regulatory agent in breast milk. Silence $\mathbf{1}$ 7. (https://doi. org/10.1186/1758-907X-1-7)

Krysiak-Baltyn K, Toppari J, Skakkebaek NE, Jensen TS, Virtanen HE, Schramm KW, Shen H, Vartiainen T, Kiviranta H, Taboureau $O$ et al. 2010 Country-specific chemical signatures of persistent environmental compounds in breast milk. International Journal of Andrology 33 270-278. (https://doi.org/10.1111/j.1365-2605.2009.00996.x)

Kucia M, Langhammer M, Gors S, Albrecht E, Hammon HM, Nurnberg G \& Metges CC 2011 High-protein diet during gestation and lactation affects mammary gland mRNA abundance, milk composition and pre-weaning litter growth in mice. Animal 5 268-277. (https://doi. org/10.1017/S1751731110001734)

Langer P 2008 The phases of maternal investment in eutherian mammals. Zoology 111 148-162. (https://doi.org/10.1016/j.zool.2007.06.007)

Lau C 2001 Effects of stress on lactation. Pediatric Clinics of North America 48 221-234. (https://doi.org/10.1016/S0031-3955(05)70296-0)

Lauritzen L, Hoppe C, Straarup EM \& Michaelsen KF 2005 Maternal fish oil supplementation in lactation and growth during the first 2.5 years 
of life. Pediatric Research 58 235-242. (https://doi.org/10.1203/01. PDR.0000169978.92437.58)

Lecoutre S \& Breton C 2014 The cellularity of offspring's adipose tissue is programmed by maternal nutritional manipulations. Adipocyte 3 256-262. (https://doi.org/10.4161/adip.29806)

Lehmann GM, Verner MA, Luukinen B, Henning C, Assimon SA, LaKind JS, McLanahan ED, Phillips LJ, Davis MH, Powers CM et al. 2014 Improving the risk assessment of lipophilic persistent environmental chemicals in breast milk. Critical Reviews in Toxicology 44 600-617. (https://doi.org/1 0.3109/10408444.2014.926306)

Lewis DS, Bertrand HA, McMahan CA, McGill HC, Carey KD \& Masoro EJ 1989 Influence of preweaning food intake on body composition of young adult baboons. American Journal of Physiology 257 R1128-R1135. (https://doi.org/10.1152/ajpcell.1989.257.6.C1128)

Lewis DS, Jackson EM \& Mott GE 1992 Effect of energy intake on postprandial plasma hormones and triglyceride concentrations in infant female baboons (Papio species). Journal of Clinical Endocrinology and Metabolism 74 920-926. (https://doi.org/10.1210/jcem.74.4.1548359)

Li J, Sheng N, Cui R, Feng Y, Shao B, Guo X, Zhang H \& Dai J 2016 Gestational and lactational exposure to bisphenol AF in maternal rats increases testosterone levels in 23-day-old male offspring. Chemosphere 163 552-561. (https://doi.org/10.1016/j.chemosphere.2016.08.059)

Liang X, Yang Q, Zhang L, Maricelli JW, Rodgers BD, Zhu MJ \& Du M 2016 Maternal high-fat diet during lactation impairs thermogenic function of brown adipose tissue in offspring mice. Scientific Reports 634345. (https://doi.org/10.1038/srep34345)

Logan CA, Rothenbacher D \& Genuneit J 2017 Postpartum smoking relapse and breast feeding: defining the window of opportunity for intervention. Nicotine and Tobacco Research 19 367-372. (https://doi. org/10.1093/ntr/ntw224)

Lopez-Soldado I, Munilla MA \& Herrera E 2006 Long-term consequences of under-nutrition during suckling on glucose tolerance and lipoprotein profile in female and male rats. British Journal of Nutrition $\mathbf{9 6}$ 1030-1037. (https://doi.org/10.1017/BJN20061949)

Lovelady CA, Garner KE, Moreno KL \& Williams JP 2000 The effect of weight loss in overweight, lactating women on the growth of their infants. New England Journal of Medicine 342 449-453. (https://doi. org/10.1056/NEJM200002173420701)

Luoto R, Laitinen K, Nermes M \& Isolauri E 2010 Impact of maternal probiotic-supplemented dietary counselling on pregnancy outcome and prenatal and postnatal growth: a double-blind, placebo-controlled study. British Journal of Nutrition 103 1792-1799. (https://doi.org/10.1017/ S0007114509993898)

Macrì S, Zoratto F \& Laviola G 2011 Early-stress regulates resilience, vulnerability and experimental validity in laboratory rodents through mother-offspring hormonal transfer. Neuroscience and Biobehavioral Reviews 35 1534-1543. (https://doi.org/10.1016/j. neubiorev.2010.12.014)

Mahmood S, Smiraglia DJ, Srinivasan M \& Patel MS 2013 Epigenetic changes in hypothalamic appetite regulatory genes may underlie the developmental programming for obesity in rat neonates subjected to a high-carbohydrate dietary modification. Journal of Developmental Origins of Health and Disease 4 479-490. (https://doi.org/10.1017/ S2040174413000238)

Makrides M, Neumann MA, Simmer K \& Gibson RA 1999 Dietary longchain polyunsaturated fatty acids do not influence growth of term infants: a randomized clinical trial. Pediatrics 104 468-475. (https://doi. org/10.1542/peds.104.3.468)

Massiera F, Saint-Marc P, Seydoux J, Murata T, Kobayashi T, Narumiya S, Guesnet P, Amri EZ, Negrel R \& Ailhaud G 2003 Arachidonic acid and prostacyclin signaling promote adipose tissue development: a human health concern? Journal of Lipid Research 44 271-279. (https://doi. org/10.1194/jlr.M200346-JLR200)

Masuyama H \& Hiramatsu Y 2014 Additive effects of maternal high fat diet during lactation on mouse offspring. PLOS ONE 9 e92805. (https://doi. org/10.1371/journal.pone.0092805)

Mayer-Davis EJ, Rifas-Shiman SL, Zhou L, Hu FB, Colditz GA \& Gillman MW 2006 Breast-feeding and risk for childhood obesity: does maternal diabetes or obesity status matter? Diabetes Care $\mathbf{2 9}$ 2231-2237. (https://doi.org/10.2337/dc06-0974)

Michaelsen KF, Larsen PS, Thomsen BL \& Samuelson G 1994 The Copenhagen Cohort Study on Infant Nutrition and Growth: breast-milk intake, human milk macronutrient content, and influencing factors. American Journal of Clinical Nutrition 59 600-611. (https://doi. org/10.1093/ajcn/59.3.600)

Mondal D, Weldon RH, Armstrong BG, Gibson LJ, Lopez-Espinosa MJ, Shin HM \& Fletcher T 2014 Breastfeeding: a potential excretion route for mothers and implications for infant exposure to perfluoroalkyl acids. Environmental Health Perspectives 122 187-192. (https://doi. org/10.1289/ehp.1306613)

Morimoto S, Calzada L, Sosa TC, Reyes-Castro LA, RodriguezGonzález GL, Morales A, Nathanielsz PW \& Zambrano E 2012 Emergence of ageing-related changes in insulin secretion by pancreatic islets of male rat offspring of mothers fed a low-protein diet. British Journal of Nutrition 107 1562-1565. (https://doi.org/10.1017/ S0007114511004855)

Mott GE \& Lewis DS 2009 Baboon model for infant nutrition. In The Baboon in Biomedical Research, pp 255-264. New York, NY: Springer. (https://doi.org/10.1007/978-0-387-75991-3_13)

Moura AS, Franco de Sá CC, Cruz HG \& Costa CL 2002 Malnutrition during lactation as a metabolic imprinting factor inducing the feeding pattern of offspring rats when adults. The role of insulin and leptin. Brazilian Journal of Medical and Biological Research 35 617-622. (https://doi. org/10.1590/S0100-879X2002000500016)

Much D, Brunner S, Vollhardt C, Schmid D, Sedlmeier EM, Brüderl M, Heimberg E, Bartke N, Boehm G, Bader BL et al. 2013 Breast milk fatty acid profile in relation to infant growth and body composition: results from the INFAT study. Pediatric Research 74 230-237. (https://doi. org/10.1038/pr.2013.82)

Munch EM, Harris RA, Mohammad M, Benham AL, Pejerrey SM, Showalter L, Hu M, Shope CD, Maningat PD, Gunaratne PH et al. 2013 Transcriptome profiling of microRNA by Next-Gen deep sequencing reveals known and novel miRNA species in the lipid fraction of human breast milk. PLOS ONE 8 e50564. (https://doi.org/10.1371/journal. pone.0050564)

Murillo-Fuentes ML, Murillo ML \& Carreras O 2003 Effects of maternal ethanol consumption during pregnancy or lactation on intestinal absorption of folic acid in suckling rats. Life Science 73 2199-2209. (https://doi.org/10.1016/S0024-3205(03)00570-8)

Murtaugh LC 2007 Pancreas and beta-cell development: from the actual to the possible. Development 134 427-438. (https://doi.org/10.1242/ dev.02770)

Nair G \& Hebrok M 2015 Islet formation in mice and men: lessons for the generation of functional insulin-producing beta-cells from human pluripotent stem cells. Current Opinion in Genetics and Development 32 171-180. (https://doi.org/10.1016/j.gde.2015.03.004)

Nathanielsz PW 2006 Animal models that elucidate basic principles of the developmental origins of adult diseases. ILAR Journal 47 73-82. (https:// doi.org/10.1093/ilar.47.1.73)

Nijland MJ, Ford SP \& Nathanielsz PW 2008 Prenatal origins of adult disease. Current Opinion in Obstetrics and Gynecology 20 132-138. (https://doi.org/10.1097/GCO.0b013e3282f76753)

Nommsen LA, Lovelady CA, Heinig MJ, Lonnerdal B \& Dewey KG 1991 Determinants of energy, protein, lipid, and lactose concentrations in human milk during the first 12 mo of lactation: the DARLING Study. American Journal of Clinical Nutrition 53 457-465. (https://doi. org/10.1093/ajcn/53.2.457)

Obermann-Borst SA, Eilers PH, Tobi EW, de Jong FH, Slagboom PE, Heijmans BT \& Steegers-Theunissen RP 2013 Duration of breastfeeding and gender are associated with methylation of the LEPTIN gene in very young children. Pediatric Research 74 344-349. (https://doi. org/10.1038/pr.2013.95)

Oosting A, Kegler D, Boehm G, Jansen HT, van de Heijning BJ \& van der Beek EM 2010 N-3 long-chain polyunsaturated fatty acids prevent excessive fat deposition in adulthood in a mouse model of postnatal nutritional programming. Pediatric Research 68 494-499. (https://doi. org/10.1203/PDR.0b013e3181f74940)

Oosting A, Verkade HJ, Kegler D, van de Heijning BJ \& van der Beek EM 2015 Rapid and selective manipulation of milk fatty acid composition in mice through the maternal diet during lactation. Journal of Nutritional Science 4 e19. (https://doi.org/10.1017/jns.2015.13)

Padmanabhan V, Cardoso RC \& Puttabyatappa M 2016 Developmental programming, a pathway to disease. Endocrinology 157 1328-40. (https://doi.org/10.1210/en.2016-1003) 
Pan IJ, Daniels JL, Herring AH, Rogan WJ, Siega-Riz AM, Goldman BD \& Sjödin A 2010 Lactational exposure to polychlorinated biphenyls, dichlorodiphenyltrichloroethane, and dichlorodiphenyldichloroethylene and infant growth: an analysis of the Pregnancy, Infection, and Nutrition Babies Study. Paediatric and Perinatal Epidemiology 24 262-271. (https://doi.org/10.1111/j.1365-3016.2010.01114.x)

Panagos PG, Vishwanathan R, Penfield-Cyr A, Matthan NR, Shivappa N, Wirth MD, Hebert JR \& Sen S 2016 Breastmilk from obese mothers has pro-inflammatory properties and decreased neuroprotective factors. Journal of Perinatology 36 284-290. (https://doi.org/10.1038/ jp.2015.199)

Parlee SD, Simon BR, Scheller EL, Alejandro EU, Learman BS, Krishnan V, Bernal-Mizrachi E \& MacDougald OA 2014 Administration of saccharin to neonatal mice influences body composition of adult males and reduces body weight of females. Endocrinology 155 1313-1326. (https:// doi.org/10.1210/en.2013-1995)

Patterson CM, Bouret SG, Park S, Irani BG, Dunn-Meynell AA \& Levin BE 2010 Large litter rearing enhances leptin sensitivity and protects selectively bred diet-induced obese rats from becoming obese. Endocrinology 151 4270-4279. (https://doi.org/10.1210/en.2010-0401)

Patti ME \& Kahn CR 1998 The insulin receptor - a critical link in glucose homeostasis and insulin action. Journal of Basic and Clinical Physiology and Pharmacology 9 89-109. (https://doi.org/10.1515/ JBCPP.1998.9.2-4.89)

Picó C, Oliver P, Sánchez J, Miralles O, Caimari A, Priego T \& Palou A 2007 The intake of physiological doses of leptin during lactation in rats prevents obesity in later life. International Journal of Obesity $\mathbf{3 1}$ 1199-1209. (https://doi.org/10.1038/sj.ijo.0803585)

Plagemann A, Heidrich I, Gotz F, Rohde W \& Dorner G 1992 Obesity and enhanced diabetes and cardiovascular risk in adult rats due to early postnatal overfeeding. Experimental and Clinical Endocrinology 99 154-158. (https://doi.org/10.1055/s-0029-1211159)

Plagemann A, Harder T, Franke K \& Kohlhoff R 2002 Long-term impact of neonatal breast-feeding on body weight and glucose tolerance in children of diabetic mothers. Diabetes Care 25 16-22. (https://doi. org/10.2337/diacare.25.1.16)

Poissonnet CM, Burdi AR \& Bookstein FL 1983 Growth and development of human adipose tissue during early gestation. Early Human Development 8 1-11. (https://doi.org/10.1016/0378-3782(83)90028-2)

Poissonnet CM, Burdi AR \& Garn SM 1984 The chronology of adipose tissue appearance and distribution in the human fetus. Early Human Development 10 1-11. (https://doi.org/10.1016/0378-3782(84)90106-3)

Powe CE, Knott CD \& Conklin-Brittain N 2010 Infant sex predicts breast milk energy content. American Journal of Human Biology 22 50-54. (https://doi.org/10.1002/ajhb.20941)

Priego T, Sánchez J, Palou A \& Picó C 2010 Leptin intake during the suckling period improves the metabolic response of adipose tissue to a high-fat diet. International Journal of Obesity 34 809-819. (https://doi. org/10.1038/ijo.2010.18)

Pundir S, Wall CR, Mitchell CJ, Thorstensen EB, Lai CT, Geddes DT \& Cameron-Smith D 2017 Variation of human milk glucocorticoids over 24 hour period. Journal of Mammary Gland Biology and Neoplasia 22 85-92. (https://doi.org/10.1007/s10911-017-9375-x)

Pundir S, Mitchell CJ, Thorstensen EB, Wall CR, Perrella SL, Geddes DT \& Cameron-Smith D 2018 Impact of preterm birth on glucocorticoid variability in human milk. Journal of Human Lactation 34 130-136. (https://doi.org/10.1177/0890334417729339)

Puttabyatappa M, Cardoso RC \& Padmanabhan V 2016 Effect of maternal PCOS and PCOS-like phenotype on the offspring's health. Molecular and Cellular Endocrinology 435 29-39. (https://doi.org/10.1016/j. mce.2015.11.030)

Quinn EA, Largado F, Borja JB \& Kuzawa CW 2015 Maternal characteristics associated with milk leptin content in a sample of Filipino women and associations with infant weight for age. Journal of Human Lactation 31 273-281. (https://doi.org/10.1177/0890334414553247)

Raab EL, Vuguin PM, Stoffers DA \& Simmons RA 2009 Neonatal exendin-4 treatment reduces oxidative stress and prevents hepatic insulin resistance in intrauterine growth-retarded rats. American Journal of Physiology: Regulatory Integrative and Comparative Physiology 297 R1785-R1794. (https://doi.org/10.1152/ajpregu.00519.2009)

Rajia S, Chen H \& Morris MJ 2010 Maternal overnutrition impacts offspring adiposity and brain appetite markers-modulation by postweaning diet.
Journal of Neuroendocrinology 22 905-914. (https://doi.org/10.1111/ j.1365-2826.2010.02005.x)

Raychaudhuri N, Thamotharan S, Srinivasan M, Mahmood S, Patel MS \& Devaskar SU 2014 Postnatal exposure to a high-carbohydrate diet interferes epigenetically with thyroid hormone receptor induction of the adult male rat skeletal muscle glucose transporter isoform 4 expression. Journal of Nutritional Biochemistry 25 1066-1076. (https:// doi.org/10.1016/j.jnutbio.2014.05.011)

Rehfeldt C \& Fiedler I 1984 Postnatal development of muscle fibers in growing skeletal muscles of laboratory mice. Archiv Fur Experimentelle Veterinarmedizin 38 178-192.

Reid DT, Eller LK, Nettleton JE \& Reimer RA 2016 Postnatal prebiotic fibre intake mitigates some detrimental metabolic outcomes of early overnutrition in rats. European Journal of Nutrition 55 2399-2409. (https://doi.org/10.1007/s00394-015-1047-2)

Ribeiro TA, Tófolo LP, Martins IP, Pavanello A, de Oliveira JC, Prates KV, Miranda RA, da Silva Franco CC, Gomes RM, Francisco FA et al. 2017 Maternal low intensity physical exercise prevents obesity in offspring rats exposed to early overnutrition. Scientific Reports 7 7634. (https://doi. org/10.1038/s41598-017-07395-2)

Rockhill KM, Tong VT, Farr SL, Robbins CL, D'Angelo DV \& England LJ 2016 Postpartum smoking relapse after quitting during pregnancy: pregnancy risk assessment monitoring system, 2000-2011. Journal of Women's Health 25 480-488. (https://doi.org/10.1089/jwh.2015.5244)

Rodrigues VST, Moura EG, Bernardino DN, Carvalho JC, Soares PN, Peixoto TC, Peixoto-Silva N, Oliveira E \& Lisboa PC 2017 Supplementation of suckling rats with cow's milk induces hyperphagia and higher visceral adiposity in females at adulthood, but not in males. Journal of Nutritional Biochemistry 55 89-103. (https://doi.org/10.1016/j. jnutbio.2017.12.001)

Romero NB, Mezmezian M \& Fidziańska A 2013 Main steps of skeletal muscle development in the human: morphological analysis and ultrastructural characteristics of developing human muscle. Handbook of Clinical Neurology 113 1299-1310. (https://doi.org/10.1016/B978-0444-59565-2.00002-2)

Rozo AV, Babu DA, Suen PA, Groff DN, Seeley RJ, Simmons RA, Seale P, Ahima RS \& Stoffers DA 2017 Neonatal GLP1R activation limits adult adiposity by durably altering hypothalamic architecture. Molecular Metabolism 6 748-759. (https://doi.org/10.1016/j. molmet.2017.05.006)

Rudolph MC, Young BE, Lemas DJ, Palmer CE, Hernandez TL, Barbour LA, Friedman JE, Krebs NF \& MacLean PS 2017 Early infant adipose deposition is positively associated with the $\mathrm{n}-6$ to $\mathrm{n}-3$ fatty acid ratio in human milk independent of maternal BMI. International Journal of Obesity 41 510-517. (https://doi.org/10.1038/ijo.2016.211)

Saben JL, Bales ES, Jackman MR, Orlicky D, MacLean PS \& McManaman JL 2014 Maternal obesity reduces milk lipid production in lactating mice by inhibiting acetyl-CoA carboxylase and impairing fatty acid synthesis. PLoS ONE 9 e98066. (https://doi.org/10.1371/journal.pone.0098066)

Sadagurski M, Landeryou T, Blandino-Rosano M, Cady G, Elghazi L, Meister D, See L, Bartke A, Bernal-Mizrachi E \& Miller RA 2014 Longlived crowded-litter mice exhibit lasting effects on insulin sensitivity and energy homeostasis. American Journal of Physiology: Endocrinology and Metabolism 306 E1305-E1314. (https://doi.org/10.1152/ ajpendo.00031.2014)

Sánchez J, Priego T, Palou M, Tobaruela A, Palou A \& Picó C 2008 Oral supplementation with physiological doses of leptin during lactation in rats improves insulin sensitivity and affects food preferences later in life. Endocrinology 149 733-740. (https://doi.org/10.1210/en.2007-0630)

Santos-Silva AP, Oliveira E, Pinheiro CR, Nunes-Freitas AL, AbreuVillaça Y, Santana AC, Nascimento-Saba CC, Nogueira-Neto JF, Reis AM, Moura EG et al. 2011 Effects of tobacco smoke exposure during lactation on nutritional and hormonal profiles in mothers and offspring. Journal of Endocrinology 209 75-84. (https://doi.org/10.1530/ JOE-10-0410)

Santos-Silva AP, Oliveira E, Pinheiro CR, Santana AC, NascimentoSaba CC, Abreu-Villaça Y, Moura EG \& Lisboa PC 2013 Endocrine effects of tobacco smoke exposure during lactation in weaned and adult male offspring. Journal of Endocrinology 218 13-24. (https://doi. org/10.1530/JOE-13-0003)

Schaefer-Graf UM, Hartmann R, Pawliczak J, Passow D, Abou-Dakn M, Vetter K \& Kordonouri O 2006 Association of breast-feeding and 
early childhood overweight in children from mothers with gestational diabetes mellitus. Diabetes Care 29 1105-1107. (https://doi. org/10.2337/dc05-2413)

Schiaffino S, Dyar KA, Ciciliot S, Blaauw B \& Sandri M 2013 Mechanisms regulating skeletal muscle growth and atrophy. FEBS Journal $\mathbf{2 8 0}$ 4294-4314. (https://doi.org/10.1111/febs.12253)

Schulz TJ \& Tseng YH 2013 Brown adipose tissue: development, metabolism and beyond. Biochemical Journal 453 167-178. (https://doi. org/10.1042/BJ20130457)

Segovia SA, Vickers MH, Zhang XD, Gray C \& Reynolds CM 2015 Maternal supplementation with conjugated linoleic acid in the setting of diet-induced obesity normalises the inflammatory phenotype in mothers and reverses metabolic dysfunction and impaired insulin sensitivity in offspring. Journal of Nutritional Biochemistry 26 1448-1457. (https://doi. org/10.1016/j.jnutbio.2015.07.013)

Sherry CL, Oliver JS \& Marriage BJ 2015 Docosahexaenoic acid supplementation in lactating women increases breast milk and plasma docosahexaenoic acid concentrations and alters infant omega 6:3 fatty acid ratio. Prostaglandins, Leukotrienes and Essential Fatty Acids 95 63-69. (https://doi.org/10.1016/j.plefa.2015.01.005)

Shrayyef MZ \& Gerich JE 2010 Normal glucose homeostasis. In Principles of Diabetes Mellitus, pp 19-35. Ed L Poretsky. Boston, MA, USA: Springer. (https://doi.org/10.1007/978-0-387-09841-8_2)

Skakkebaek NE, Rajpert-De Meyts E, Jørgensen N, Main KM, Leffers $\mathbf{H}$, Andersson AM, Juul A, Jensen TK \& Toppari J 2007 Testicular cancer trends as 'whistle blowers' of testicular developmental problems in populations. International Journal of Andrology 30 198-204; discussion 204-205. (https://doi.org/10.1111/j.1365-2605.2007.00776.x)

Solomon GM \& Weiss PM 2002 Chemical contaminants in breast milk: time trends and regional variability. Environmental Health Perspectives 110 A339-A347. (https://doi.org/10.1289/ehp.021100339)

Srinivasan M, Aalinkeel R, Song F, Lee B, Laychock SG \& Patel MS 2000 Adaptive changes in insulin secretion by islets from neonatal rats raised on a high-carbohydrate formula. American Journal of Physiology: Endocrinology and Metabolism 279 E1347-E1357. (https://doi. org/10.1152/ajpendo.2000.279.6.E1347)

Srinivasan M, Song F, Aalinkeel R \& Patel MS 2001 Molecular adaptations in islets from neonatal rats reared artificially on a high carbohydrate milk formula. American Journal of Physiology: Endocrinology and Metabolism 12 575-584.

Srinivasan M, Mahmood S \& Patel MS 2013 Metabolic programming effects initiated in the suckling period predisposing for adult-onset obesity cannot be reversed by calorie restriction. American Journal of Physiology: Endocrinology and Metabolism 304 E486-E494. (https://doi. org/10.1152/ajpendo.00519.2012)

Stringer JM, Pask AJ, Shaw G \& Renfree MB 2014 Post-natal imprinting: evidence from marsupials. Heredity 113 145-155. (https://doi. org/10.1038/hdy.2014.10)

Sun B, Purcell RH, Terrillion CE, Yan J, Moran TH \& Tamashiro KL 2012 Maternal high-fat diet during gestation or suckling differentially affects offspring leptin sensitivity and obesity. Diabetes 61 2833-2841. (https:// doi.org/10.2337/db11-0957)

Sylvetsky AC, Gardner AL, Bauman V, Blau JE, Garraffo HM, Walter PJ \& Rother KI 2015 Nonnutritive sweeteners in breast milk. Journal of Toxicology and Environmental Health, Part A 78 1029-1032. (https://doi. org/10.1080/15287394.2015.1053646)

Tang WY \& Ho SM 2007 Epigenetic reprogramming and imprinting in origins of disease. Reviews in Endocrine and Metabolic Disorders 8 173-182. (https://doi.org/10.1007/s11154-007-9042-4)

Tavares do Carmo MG, Oller do Nascimento CM, Martin A \& Herrera E 1999 Ethanol intake during lactation impairs milk production in rats and affects growth and metabolism of suckling pups. A/cohol 18 71-76. (https://doi.org/10.1016/S0741-8329(98)00070-6)

Taylor NA \& Wilkinson JG 1986 Exercise-induced skeletal muscle growth. Hypertrophy or hyperplasia? Sports Medicine 3 190-200. (https://doi. org/10.2165/00007256-198603030-00003)

Thakkar SK, Giuffrida F, Cristina CH, De Castro CA, Mukherjee R, Tran LA, Steenhout P, Lee LY \& Destaillats F 2013 Dynamics of human milk nutrient composition of women from Singapore with a special focus on lipids. American Journal of Human Biology 25 770-779. (https://doi. org/10.1002/ajhb.22446)

Thorens B \& Mueckler M 2010 Glucose transporters in the 21st century. American Journal of Physiology: Endocrinology and Metabolism 298 E141-E145. (https://doi.org/10.1152/ajpendo.00712.2009)

Ting JW \& Lautt WW 2006 The effect of acute, chronic, and prenatal ethanol exposure on insulin sensitivity. Pharmacology and Therapeutics 111 346-373. (https://doi.org/10.1016/j.pharmthera.2005.10.004)

Tirone TA \& Brunicardi FC 2001 Overview of glucose regulation. World Journal of Surgery 25 461-467. (https://doi.org/10.1007/ s002680020338)

Torres AG, Ney JG, Meneses F \& Trugo NM 2006 Polyunsaturated fatty acids and conjugated linoleic acid isomers in breast milk are associated with plasma non-esterified and erythrocyte membrane fatty acid composition in lactating women. British Journal of Nutrition 95 517-524. (https://doi. org/10.1079/BJN20051645)

Tweed JO, Hsia SH, Lutfy K \& Friedman TC 2012 The endocrine effects of nicotine and cigarette smoke. Trends in Endocrinology and Metabolism 23 334-342. (https://doi.org/10.1016/j.tem.2012.03.006)

Vickers MH, Gluckman PD, Coveny AH, Hofman PL, Cutfield WS, Gertler A, Breier BH \& Harris M 2005 Neonatal leptin treatment reverses developmental programming. Endocrinology 146 4211-4216. (https://doi.org/10.1210/en.2005-0581)

Vogt MC, Paeger L, Hess S, Steculorum SM, Awazawa M, Hampel B, Neupert S, Nicholls HT, Mauer J, Hausen AC et al. 2014 Neonatal insulin action impairs hypothalamic neurocircuit formation in response to maternal high-fat feeding. Cell 156 495-509. (https://doi.org/10.1016/j. cell.2014.01.008)

Wang QA, Tao C, Gupta RK \& Scherer PE 2013 Tracking adipogenesis during white adipose tissue development, expansion and regeneration. Nature Medicine 19 1338-1344. (https://doi.org/10.1038/nm.3324)

Weber M, Grote V, Closa-Monasterolo R, Escribano J, Langhendries JP, Dain E, Giovannini M, Verduci E, Gruszfeld D, Socha P et al. 2014 Lower protein content in infant formula reduces BMI and obesity risk at school age: follow-up of a randomized trial. American Journal of Clinical Nutrition 99 1041-1051. (https://doi.org/10.3945/ajcn.113.064071)

Wells JC 2014 Adaptive variability in the duration of critical windows of plasticity: Implications for the programming of obesity. Evolution, Medicine, and Public Health 2014 109-121. (https://doi.org/10.1093/ emph/eou019)

White RB, Biérinx AS, Gnocchi VF \& Zammit PS 2010 Dynamics of muscle fibre growth during postnatal mouse development. BMC Developmental Biology 10 21. (https://doi.org/10.1186/1471-213X-10-21)

Xiao Q, Williams SM, Grayson BE, Glavas MM, Cowley MA, Smith MS \& Grove KL 2007 Excess weight gain during the early postnatal period is associated with permanent reprogramming of brown adipose tissue adaptive thermogenesis. Endocrinology 148 4150-4159. (https://doi. org/10.1210/en.2007-0373)

Young BE, Patinkin Z, Palmer C, de la Houssaye B, Barbour LA, Hernandez T, Friedman JE \& Krebs NF 2017a Human milk insulin is related to maternal plasma insulin and BMI: but other components of human milk do not differ by BMI. European Journal of Clinical Nutrition 71 1094-1100. (https://doi.org/10.1038/ejcn.2017.75)

Young BE, Patinkin ZW, Pyle L, de la Houssaye B, Davidson BS, Geraghty S, Morrow AL \& Krebs N 2017b Markers of oxidative stress in human milk do not differ by maternal BMI but are related to infant growth trajectories. Maternal and Child Health Journal 21 1367-1376. (https:// doi.org/10.1007/s10995-016-2243-2)

Zorn AM 2008 Liver development. StemBook (Internet). Cambridge (MA): The Harvard Stem Cell Institute. (available from: http://www.ncbi.nlm. nih.gov/books/NBK27068/)

Received 24 December 2017

First decision 12 February 2018

Revised manuscript received 15 April 2018

Accepted 11 May 2018 